Savunma Bilimleri Dergisi

The Journal of Defense Sciences

Mayıs/May 2019, Cilt/Volume 18, Sayi/Issue 1.

ISSN (Bas1l1) : 1303-6831 ISSN (Online): 2148-1776

\title{
Türkiye'de Savunma Sanayi Gelişim Tarihi İçinde Makine ve Kimya Endüstrisi Kurumunun Kuruluş Dönemi Faaliyetlerinin Analizi*
}

\author{
Hüsnü ÖZLÜ**
}

$\ddot{O} z$

Osmanlı Devleti'nin kuruluşundan 17'nci yüzylla kadar her dönemde, harp sanayi faaliyetlerine önem verilmiş ve bu doğrultuda yapılanmaya gidilmiştir. Ancak 19 'uncu yüzylldan itibaren dünyada meydana gelen gelişmelerin gerisinde kalan Osmanl Devleti son dönemlerinde bu etkinliğini sürdürememiştir. Devletin son yıllarında harp sanayi alanında yeni bir yapılanmaya gidilmiş ve "İmalât-ı Harbiye-i Umumiye Müdürlüğ̈̈" kurularak bu alanda çalışmalara önem verilmiştir.

Cumhuriyetin ilanından sonra kurulan "Askerî Fabrikalar Umum Müdürlüğ̈̈" 1923 ile 1950 yıllart arasında harp sanayinin etkinliğini ve sorumluluğunu yüklenmişstir. Millî Mücadele'nin zaferle sonuçlanmasından sonra Ankara'da temelleri atılan silah tamirhanelerinin yenilenmesi ve askerî fabrikaların kurulması için çalışmalar başlatılmış ve bu iş için en uygun yer olarak Kırıkkale belirlenmiştir. Ankara'da 1921 yllinda kurulan silah tamirhanesi ve marangoz atölyelerinden sonra bu bölgede askerî fabrikaların kurulması çalışmaları hiz kazanmıştır.

Cumhuriyetin kuruluşunu takip eden on ylllk dönem sonunda başlayan savunma sanayi kuruluş faaliyetleri çerçevesinde, 1933-1939 yıllarl arasındaki dönemde, savunma sanayisine de temel teşkil edecek endüstrilere yönelik yatırımlar

\footnotetext{
* Bu makale; Yazarın, 2006 yılında Dokuz Eylül Üniversitesi, Atatürk İlkeleri ve İnkılap Tarihi Enstitüsünde kabul edilen, “İkinci Dünya Savaşı’ndan Günümüze Türkiye’de Savunma Sanayinin Gelişimi (1939-1990)" adlı doktora tezinden yazılmıştır.

*** Doç.Dr.Öğ.Alb., Millî Savunma Üniversitesi, Alparslan Savunma Bilimleri Enstitüsü Müdürü, hozlu@kho.edu.tr.

Geliş Tarihi/Received:26.03.2019

Kabul Tarihi/Accepted:08.04.2019 Araştırma Makalesi/Research Article
} 
başarıyla sonuçlandırılmıştır. Bu süreçte savunma sanayi alanında, özellikle havacıllk sektöründe önemli gelişmeler yaşanmıştır.

İkinci Dünya Savaşı'nın dışında kalmayı başaran Türkiye Cumhuriyeti Devleti, bu dönemde kendi kaynakları ile yetinmiş, ekonomik yetersizlikler ve savaş koşulları nedeniyle silah sanayi alanında proje üretimi ve teknoloji transferi gerçekleştirememiştir. Böylece sermayeleri yetersiz hâle gelen askerî fabrikaların birçoğu kapanma noktasına gelmiştir. Bu dönemde askerî fabrikaların, modern bir ordunun isteklerini karşılayacak kapasiteye ulaştırılması ve yeniden teşkilatlandırllması zorunlu görülmüş̧ür. Bu durumun bir sonucu olarak savunma sanayi alanında yeni bir yapılanmaya ihtiyaç duyulmuştur. İşte bu ihtiyaçlar sonucunda 15 Mart 1950 tarih ve 5591 sayll kanun ile Makine ve Kimya Endüstrisi Kurumu kurulmuş ve Askerî Fabrikalar Umum Müdürlügünden devredilen fabrika ve tesisler ile yeni bir yapılanmaya gidilmiştir.

Anahtar Kelimeler: Askerî Fabrika, Harp Sanayi, Makine ve Kimya Endüstrisi Кигити.

\title{
Analysis of the Estabishment Period Operations of the Mechanical and Chemical Industry Institution Within the Development History of Defence Industry in Turkey
}

\begin{abstract}
From the establishment of the Ottoman Empire to the 17th century, in every period, importance was given to war industry activities and structured accordingly. However, the Ottoman Empire, which lagged behind the developments in the world since the 19th century, could not sustain this activity in the last period. In the last years of the State, "General Imalatt-ı Harbiye-i Directorate" was established in order to recover the war industry field and the studies have been given importance in this field.

"General Military Factories Directorate" which was established after the proclamation of Republic took over the activity and responsibility of the war industry between the 1923 and 1950 years. After the victory of the National Struggle, the researches was started in order to renew the weapon repair shops which were laid in Ankara and to establish the other factories in the Anatolia and Kirlkkale was determined as the most suitable place for this work. After the armory
\end{abstract}


Türkiye'de Savunma Sanayi Gelişim Tarihi İçinde Makine ve Kimya

Endüstrisi Kurumunun Kuruluş Dönemi Faaliyetlerinin Analizi

and carpenter workshops established in 1921 in Ankara, the establishment of military factories in this region has accelerated.

The investments which will form the basis for the defence industry have been completed successfully by depending on the implementation of the 1st and 2nd industrial plans in the 1933-1939 period within the framework of the establisment activities of the defence industry, which started at the end of the ten-year period following the establishment of the Republic. In this process, significant developments occurred in the defence industry, especially in the aviation sector.

The State of the Republic of Turkey, managed to stay out of the Second World War, has been satisfied with their own resources and any project production and technology transfer could not be realized in the field of defence industry due to economic deficiencies and war conditions. Therefore, many of the military factories whose capital was inadequate came to the point of closure. In this period, it was regarded as necessary that military factories were required to reach the capacity to meet the demands of a modern army and to be reorganized. As a result of this situation, a new restructuring was needed in the field of defence industry. As a result of these needs, Machinery and Chemical Industry Institution was established with the law no. 5591 dated March 15, 1950.

Keywords: Military Factory, War Industry, Machinery and Chemical Industry Institution.

\section{Giriş}

Savunma sanayi, bir ülkenin silahlı kuvvetleri için gerekli olan taktik, stratejik, savunma ve taarruz amacına yönelik silah sistemlerini tasarlayan, geliştiren ve üreten, diğer sanayi kolları ile de yakın etkileşim içerisinde bulunan işletmeler topluluğudur.

Türk savunma sanayinin tarihsel gelişim sürecinde, Osmanlı Devleti, 15 'inci yüzyılın ikinci yarısı ile 16'ncı yüzyılın ilk yarısında askerî üstünlüğe sahip olmuştur (Agoston, 2012: s.137). Yükselme döneminde çağının bir hayli ilerisinde olan Osmanlı harp sanayi teşkilatı bu üstünlüğünü 17'nci yüzyıl sonlarına kadar devam ettirmiştir. 18'inci yüzylldan itibaren Avrupa'da başlayan teknolojik gelişmeler ve seri üretime dayalı harp sanayi kurma girişimleri Osmanlı Devleti'nin 19'uncu yüzyılda savunma sanayi alanında geride kalmasına yol açmıştır (Tetik, Soyluer, 2013: s.119). Bu süreçte özellikle 18'inci yüzyılda acil 
silah ihtiyacı karşısında silah ithalatına yönelinmiş ve ordunun talepleri bu yolla karşılanmaya çalışılmıştır (Yeşil, 2016: s. 135). Birinci Dünya Savaş1 yıllarında savunma sanayi alanında önemli bir gelişme gösteremeyen Osmanlı Devleti, Türkiye Cumhuriyeti Devleti'ne de savunma sanayine ilişkin ciddi bir altyapı devredememiştir.

Fatih Sultan Mehmet devrinde bu günkü Galata ile Salıpazarı arasında yer alan ve Tophane olarak bilinen yerde "Top Asitanesi" adı ile harp sanayinin ilk merkezi kurulmuştur. Bu yüzyılda Tophane-i Amire, Cebehane-i Amire, Baruthane-i Amire ve Tersane-i Amire Osmanlı Devleti'ne Avrupa'nın en geniş askerî sanayisini kazandırmıştır (Agoston, 2012: s.138). Tophane-i Amire'de yapılan toplarda kullanılacak gülleler Hasköy'de Piri Paşa'da dökülmüş, İkinci Beyazıt devrinde ise İstanbul'da ilk Baruthane açılmıştır. 18'inci yüzyıl başlarında bu baruthaneler ihtiyacı karşılamayınca Bakırköy'de "Baruthane-i Amire" adı ile büyük bir fabrika kurulmuştur. Ayrıca Gelibolu ve Selanik'te de baruthaneler açılarak bunlar "Baruthaneler Nazırlı̆̆ı" adı ile kurulan nezarete bağlanmıştır. İlk tüfek fabrikası İstanbul Kuruçeşme'de kurulmuş ve bu fabrika 1873 y1lında Tophane'ye taşınmıştır. Osmanlı devri harp sanayinin önemli fabrikalarından bir tanesi de 1829 yılında Zeytinburnu'nda kurulan demirhanedir. Bu fabrika silah imali için gerekli malzemeleri üretmektedir. Ayrıca İstanbul dışında da silah sanayinin kereste ihtiyacı için 1878 yılında Hendek'te ve 1893 yılında Bayramiç’te kereste fabrikaları, barutun hammaddesi olan güherçile imali için de Konya ve Kayseri’de güherçile kalhaneleri açılmıştır (Özlü, 2006: s.1).

Osmanlı Devleti döneminde kurulan ve İstanbul'da toplanmış olan askerî fabrikalar Balkan Savaşları döneminde Anadolu'ya taşınmak istenmiş ancak Birinci Dünya Savaşı'nın başlaması ile bu düşünce gerçekleştirilememiştir. Birinci Dünya Savaşı'ndan yenik çıkan Osmanlı Devleti, imzaladığı Mondros Ateşkes Antlaşması gereği askerî fabrikaları kapatmak zorunda kalmışırı. Bu arada 1832 yılından itibaren faaliyetlerini sürdüren Seraskerlik Kurumu, 22 Haziran 1908 tarihinde "Harbiye Nezareti" adı altında yeniden teşkilatlandırılmış, bir yıl sonra da bu nezarete bağlı olarak "Imalât-ı Harbiye-i Umumiye Müdürlüğü" kurulmuş ve silah sanayinin tüm teşkilatı bu müdürlüğe bağlanmıştır. Ankara Silah Tamirhanesi, Ankara Top Mühimmathanesi, Marangozhane, Eskişehir Silah Tamirhanesi, Keskin Fişek İmalathanesi, Kayseri ve Konya Tamirhaneleri, Erzurum İş Ocağı bu yıllarda İmalât-1 Harbiye-i Umumiye Müdürlüğüne bağlı çalışan fabrika ve tesislerdir (Özlü, 2006: s.2). 
Türkiye'de Savunma Sanayi Gelişim Tarihi İçinde Makine ve Kimya

Endüstrisi Kurumunun Kuruluş Dönemi Faaliyetlerinin Analizi

Millî Mücadele döneminde Anadolu'daki ilk askerî fabrikaların kuruluşu, Mustafa Kemal Atatürk'ün Anadolu'ya geçmesi ve Millî Mücadele'ye başlaması ile silah tamiri ve cephane ve harp malzemesi imali işlerinin Anadolu'da yapılması amacıyla gerçekleşmiştir. İşgal altındaki İstanbul'da bulunan askerî fabrikalardan "Karakol Cemiyeti" ve "Mim Mim" grubu ve diğer gizli grupların çalışmaları ile kaçırılan makine ve ustalarla başlanan harp sanayi oluşturma gayretleri, kurtuluş mücadelesinde sonuç vermiş ve bundan sora millî harp sanayinin sağlam temelleri bizzat Mustafa Kemal Paşa tarafından atılmıştır. Bu süreçte İmalât-1 Harbiye-i Umumiye Müdürlügüne bağlı çalışan fabrika ve tesisler 1921 yılı Ocak ayından itibaren yeni bir teşkilat olarak kurulan "Askerî Fabrikalar Umum Müdürlügüne" bağlanmış ve daha sistemli çalışmaya başlamışlardır.

Millî Mücadele'nin zaferle sonuçlanmasından sonra, Ankara'da temelleri atılan silah tamirhanelerinin yenilenmesi ve diğer fabrikaların da Anadolu'da kurulması için çalışmalar başlatılmış ve bu iş için en uygun yer olarak Kırıkkale belirlenmiştir. Ankara'da 1921 yılında kurulan silah tamirhanesi ve marangoz atölyelerinden sonra, 1923 yılında yine Ankara'da Fişek Fabrikası, 1925 y1lında Kırıkkale'de Topçu Mühimmat Fabrikası, 1926 yılında Kuvvet Merkezi ile pirinç döküm ve haddehanesi, 1930 yılında Ankara'da Kapsül ve İmla Fabrikası ve Kırıkkale'de çelik döküm haddehanesi, 1937 yılında Kırıkkale'de Nitroselüloz Barut Fabrikası ve top fabrikasının temelleri atılmıştır.

İstanbul'da kurulmuş olan Av ve Revolver Fişekleri Fabrikası 1929 yılında yine Elmadağ'da kurulmuş olan barut fabrikası 1934 yılında ve 1934 yılında Kızılay tarafından yaptırılan gaz maskesi fabrikası da 1944 yılında askerî fabrikalara devredilmiştir. Bu fabrikalardan başka Anadolu'nun çeşitli yerlerinde de askerî fabrika ve tesisler kurulmuş olup bunlardan en önemlileri: Çorlu ve Çanakkale'de Silah Tamirhanesi, İzmir Halkapınar Silah Fabrikası, Akyazı Kereste Fabrikası, Kırıkkale Nal Fabrikası, Konya ve Kayseri Güherçile Kalhaneleridir (Özlü, 2006: s.1).

Askerî Fabrikalar Umum Müdürlüğü çatısı altında birleşmiş olan savunma sanayisinde, İkinci Dünya Savaşı sonrasında ortaya çıkan şartların gereği olarak yeni bir düzenlemeye ihtiyaç duyulmuş ve 15 Mart 1950 tarihinde Makine ve Kimya Endüstrisi Kurumu kurulmuştur.

1940'lı yılların ortasına kadar ve Amerikan yardımlarının başlamasından önce, Türk ordusunun silah ve mühimmat ihtiyacını karşılamayı üstlenmiş olan 
askerî fabrikaların dönemin koşullarında çok önemli hizmetler yaptığını görmekteyiz. Askerî fabrikaların iktisadî devlet teşekkülü hâline dönüşmesinde etkili olan en önemli faktörlerin başında askerî yardımlar gelir. Askerî yardımların başlaması ile birlikte bu fabrikaların silah ve mühimmat üretimi faaliyetleri durma noktasına gelmiş ve sivil ihtiyaca yönelik çalışmaya başlamıştır.

İkinci Dünya Savaşı'ndan sonra dış savunma yardımı nedeniyle, cumhuriyetin ilk yıllarında başlatılan, ancak devlet desteğinin bulunmaması nedeniyle daha fazla gelişemeyen savunma sanayi faaliyetleri yarım kalmıştır. Bununla birlikte, 1960'lı y1llarda Türkiye'nin bölgesel sorunları, 1963 ve 1967 Kıbrıs bunalımları ve özellikle Kıbrıs Barış Harekâtı ve bu harekât sonrasında Türkiye'ye uygulanan silah ambargosu, millî kaynaklara dayalı bir savunma sanayinin geliştirilmesi gereğini ortaya koymuştur. 1974 sonrasında kurulan Kara, Deniz ve Hava Kuvvetleri Güçlendirme Vakıfları bu anlayışla oluşturulmuş ve bu alanda yatırımlar başlatılmıştır.

\section{Makine ve Kimya Endüstrisi Kurumunun Kuruluşu ve Faaliyet Alanı}

Cumhuriyetin ilanından sonra Türkiye Cumhuriyeti Devleti'nin kurumsal ve iktisadi şekillenmesine bağlı olarak silah sanayinin gelişimi, Askerî Fabrikalar Umum Müdürlüğü tarafindan yürütülmüştür. Başlangıçta bu teşkilat silah sanayi alanında önemli hizmetler yapmış ve bu alanda Türkiye'nin ihtiyaçlarını karşılamıştır. Ancak, Askerî Fabrikalar Umum Müdürlüğü aracılığı ile sürdürülen silah sanayi 1940'l1 yıllarda durma noktasına gelmiştir. Bu noktaya gelinmesinde elbette ki Askerî Fabrikalar Umum Müdürlüğü üretimlerinin yetersizliği ve iyi yönetilememesinin rolü olduğu kadar, dünyada ve ülkemizdeki genel ekonomik sıkıntılar da etkili olmuştur. İkinci Dünya Savaşı'nın dışında kalmayı başaran Türkiye, bu dönemde kendi kaynakları ile yetinmiş, ekonomik yetersizlikler ve savaş koşulları nedeniyle silah sanayi alanında proje üretimi ve teknoloji transferi gerçekleştirememiş̧ir. Böylece sermayeleri yetersiz hâle gelen askerî fabrikaların birçoğu terkedilmiştir (Tanyer, 1995:s.67). İhtiyaçlara tam cevap veremeyen bu harp sanayi tesisleri ekonomik olma niteliklerini de kaybetmişlerdir. $\mathrm{Bu}$ nedenle askerî fabrikaların modern bir ordunun isteklerini karşılayacak kapasiteye ulaştırılması için yeniden teşkilatlandırılması zorunlu görülmüştür. Bu durumun bir neticesi olarak savunma sanayi alanında yeni bir yapılanmaya ihtiyaç duyulmuştur. İşte bu ihtiyaçlar sonucunda Makine ve Kimya Endüstrisi Kurumu kurulmuştur. 
Türkiye'de Savunma Sanayi Gelişim Tarihi İçinde Makine ve Kimya

Endüstrisi Kurumunun Kuruluş Dönemi Faaliyetlerinin Analizi

MKEK'nin gelişimi konusunda hazırlanmış olan raporda MKEK'nin kuruluş amacı şöyle ifade edilmektedir: "Savunmamızı, icap eden en yüksek kudretle teçhiz etmek, mümkün olduğu kadar büyük ölçüde yurt sanayi kalkınmasına hizmet etmek, bu iki geniş hizmeti ahenkli ve rasyonel bir şekilde başarmaktır" (MKEK Arşivi, R.40, R.E, G.3, K.163, D.139.).

Böylece bu amaca 15.03.1950 tarih ve 5591 sayılı kanunla Askerî Fabrikalar Umum Müdürlüğünün MKEK'ye dönüştürülmesiyle ulaş1lmaya çalış1lmıştır. (Resmi Gazete, 15. 03. 1950, Kanun No: 5591, s.18093.) EK-1'de yer alan 5591 say1lı kanunun amac1 şu şekilde özetlenebilir; "Millî savunmanın ihtiyaç duyduğu siparişlerin karşılanması ve kurumun ekonomik olma özelliğini sürekli koruyabilmesi için öteki Kamu İktisadi Teşebbüslerinin çalışmalarında uygulanan yöntemlere göre faaliyetlerini sürdürebilmesidir". Aynı kanunun birinci maddesine göre, MKEK İşletmeler Bakanlığına bağlanmıştır. Merkezi Ankara'da bulunan kurum, 3460 say1l "Sermayenin tamamı devlet tarafindan verilmek suretiyle kurulan iktisadi teşekküllerin teşkilatıyla idareleri ve murakabeleri hakkında kanun"a tabi olup, tüzel kişiliğe sahiptir (MKEK Arşivi, R.40-R.E-G.3, K.163, D.141; ayrica bk. Tanyer, a.g.m., s.72).

1 Nisan 1950 tarihinde iktisadi bir devlet teşekkülü olarak faaliyete geçen MKEK üç sene gibi kısa bir zamanda faaliyetlerini arttırarak 1950 yılında 30 milyon civarında olan iş hacmini iki katına yükseltmeyi başarmıştır (BCA, 030.01 / 76480.12 / E9).

MKEK kuruluşu ile birlikte kurumun bünyesine katılan uçak fabrikası vasıtasıyla Türkiye'de uçak imalatı ve ihracatı, ilk demir çelik saç mamulleri üretimi, ilk demiryolu rayı üretimi, ilk çelik çekme boru imali ve ilk takım tezgâhı, tekstil makineleri kutuları imali MKEK tarafından yapılmıştır ("Mühimmat Üretimi ve MKEK', Temmuz-Ağustos, 1993: s.109).

MKEK, kuruluş yıllarında silahlı kuvvetlerimizin savunma araç ve gereçlerini ve sivil sektörün bir kısım ihtiyaçlarını karşılayan kendi sahasında yurdumuzun en büyük sanayi kuruluşu olma özelliğine kavuşmuş, sermayesinin tamamı Türkiye Cumhuriyeti Devleti hazinesince ödenmiş bir kamu iktisadi teşebbüsüdür.

5591 sayılı kanunun 2'nci maddesine göre MKEK'nin yapacağı işler şu şekilde tespit edilmiştir (MKEK Arşivi, R.40, R.E, G.3, K.161, D.133-137, ayrıca bkz., Resmî Gazete, 15. 03. 1950, Kanun No: 5591, s. 18093). 
a. Her çeşit silah, mühimmat ve patlayıcı maddelerle askerî ihtiyaçlara yarayan aletler, vasitalar, makineler, tesisler ve diğer her türlü eşya ve levazım ve yedek parçalar üretmek ve seri hâlinde büyük ve küçük tadil ve ıslah işlerini ve diğer tamirleri yapmak.

b. Tesisleri ve makineleri ile karşılayabileceği sivil ihtiyaçlara ait her türlü üretim ve tamiratı yapmak.

c. 4374 sayll kanunun birinci maddesinde yazll tekel maddelerini yapmak.

d. a,b,c, maddelerinde sayllan işleri görmek üzere lüzumlu her türlü tesisleri kurmak ve mevcutlarını da tevzi ve islah etmek.

e. $\quad$ a ve b firkalarinda yazıl maddelerin ticaretini yapmak.

MKEK, kuruluş yıllarında millî savunma ve sivil kurumlara yönelik ihtiyaçları karşılamak amacıyla başlattığı çalışmalarda önceliklerini tespit etmiş, bunları da şu şekilde belirtmiştir;

"Millî savunma ihtiyaçlarına yönelik çalı̧̧malarda; kurum ulusal savunmaya yönelik asgari siparişi temin edecek ve bunları kendine bağll askerî fabrikaları çalıştıracak şekilde yapılandıracaktır. Amerika ile yapılan görüşmelerden alınan sonuçlar çerçevesinde de fabrikaların ihtiyaçlarının karşılanması sağlanacaktır. Ayrıca, geleceği tehlikede olan Kırıkkale Tüfek Fabrikasının verimli hâle getirilmesi için planlama yapılacaktır." (BCA, 640.051, MKEK Yönetim Kurulu Karar Defteri, 39'uncu oturum, 08.01.1951).

"Sivil ihtiyaçlara yönelik çalışmalarda ise; Ziraat aletlerinin imalatını birinci plana alarak bunun için gerekli olan alt yapının hazırlanması, madenlerimizin işletilmesi için gerekli maden teçhizatı ve makinelerinin yapımının ele alınması, bunların dışında kurumun, mensucat makineleri, su saatleri, vagon dingilleri, ray, soba, yüksek kaliteli çelik, bakır ve pirinç mamullerinden birçok endüstri teçhizatının yapımı gelmektedir.” (BCA, 640.051, MKEK Yönetim Kurulu Karar Defteri, 39'uncu oturum, 08.01.1951).

Görüldügü gibi MKEK askerî ihtiyaçları karş1lama görevini sürdürürken bir taraftan da sivil endüstri ihtiyaçlarını karşılamak üzere de yapılanmıştır.

Askerî Fabrikalar Umum Müdürlüğünden Makine ve Kimya Endüstrisi Kurumuna devir olan askerî fabrikaların genel durumu üzerinde durulması gereken bir husustur. Bu çerçevede, 5591 sayılı kanunun 13'üncü maddesinde Askerî Fabrikalar Umum Müdürlüğünden, MKEK'ye devredilen fabrika ve tesisler belirtilmiştir (Tanyer, 1995: s.73). MKEK bünyesine katılan fabrikalar şunlardır: 
Türkiye'de Savunma Sanayi Gelişim Tarihi İçinde Makine ve Kimya

Endüstrisi Kurumunun Kuruluş Dönemi Faaliyetlerinin Analizi

a. Malzeme Fabrikaları:

1- Kırıkkale Çelik Fabrikası

2- Kırıkkale Pirinç Fabrikası

b. Makine Fabrikaları:

1- Kırıkkale Top Fabrikası

2- Kırıkkale Tüfek Fabrikası

3- Ankara Silah Fabrikası

4- Ankara Marangoz Fabrikası

5- Mamak Maske Fabrikası

c. Mühimmat Fabrikaları:

1- Kırıkkale Mühimmat Fabrikası

2- Ankara Fişek Fabrikası

3- Silahtarağa Av Fișek Fabrikası

4- Kayaş Kapsül ve İmla Fabrikası

d. Kimya Fabrikaları:

1- Kırıkkale Barut Fabrikası

2- Elmadağ Barut Fabrikası

3- Bakırköy Barut Fabrikası

4- Konya Güherçile Kalhanesi

e. Elektrik Santrali:

1- Kırıkkale Kuvvet Merkezi

Askerî fabrikalar kurulurken, her tesisin o günün en modern teknolojileriyle donatılması hususuna dikkat edilmiştir. Ancak zaman içerisinde teknolojik gelişmeyi takip edebilmek mümkün olamamıştır. Fabrikalarda, mevcut tesislerin en yenileri bile MKEK'nin kuruluş yıllarında 12-15 senelik olup, bazı tesisler çok eski tarihlerden kalmadır. Oysaki Batı ülkelerinde İkinci Dünya Savaşı ve onu takip eden yıllarda makine sahasında büyük gelişmeler olmuştur (MKEK Arşivi, R.40, R.E, G.3, K.163, D.139).

Askerî fabrikaların Ankara ve civarında kurulmuş olanları, enerji, hammadde, iklim, işçi kalitesi, sosyal şartlar, piyasa, nakliye gibi faktörler bakımından sorunlar yaşamasına rağmen, bu tesisler verimli hâle dönüştürülmüştür. Bu konuda en sıkıntılı tesis, makinelerinin eksikliği dolayısı ile ekonomik olma özelliğini kaybetmiş olan Silahtarağa Av Fişek Fabrikasıdır. 
Devir sürecinde askerî fabrikaların bazı üniteleri üretim yöntemleri bakımından modernize edilememiş, ucuz ve seri üretim yapamaz duruma gelmiştir. Fabrikalar arasında rasyonel bir fabrikasyonun icap ettirdiği koordinasyon kurulamadığ1 için üretilen malzeme ve ürünler birbirini tamamlayamamıştır. Dolayısı ile kâra dayalı bir işletme anlayışı da gelişmemiştir. Fabrika ve tesisler kuruldukları zamana göre, ihtiyacı karşılayabilecek düzeyde olmasına rağmen, ilerleyen yıllarda Türk ordusunun ihtiyaçlarının artarak değişmesi, bunun yanında İkinci Dünya Savaşı'ndan sonra orduların kullandıkları silah ve mühimmatta geniş ölçüde motorize ve mekanize gelişmeler kaydedilmesi nedenleriyle yetersiz kalmışlardır.

Ayrıca, askerî fabrikalar dışında kalıp da Millî Savunma Bakanlığınca işletilen fabrika ve sabit tamirhaneler, yasanın 19'uncu maddesi uyarınca, kurumun isteği ve Millî Savunma Bakanlığı ile İşletmeler Bakanlığının teklifi üzerine, Bakanlar Kurulu kararı ile kuruma devredilmiştir (Tanyer, 1995: s.73). Askerî fabrikaların MKEK bünyesine katılmasından sonra, dönemin koşulları neticesinde Türkiye'de tarımsal faaliyetlere hız verilmesi nedeniyle bu fabrikalarda ülkemizin ihtiyaç duyduğu ziraat aletleri ile yedek parçaları üretimi düşünülmüş ve uygulamaya başlanmıştır. Ancak bu süreçte, özellikle, Türk Hava Kurumuna ait uçak fabrikası iş konusunda sıkıntı yaşamaya başlamış ve 19,5 milyon TL'ye mâl olan bu fabrika kapanma tehlikesi ile karşı karşıya kalmıştır (Cumhuriyet, 16 Ocak 1951).

Askerî fabrikalardan intikal eden tesislerin tamamı askerî amaçlarla harp sanayi için kurulmuş olduklarından genellikle iktisadî amaçlara yönelik değildir ve modern harp sanayi üretimi konusunda da yeterli olamamışlardır. Bu fabrikalar o dönemin üstün teknolojisi ile donatılamamış ve ilerleyen dönemde de kendilerini yenileyemediği için sürekli üretim kapasiteleri düşmüştür (MKEK Arşivi, R.40, R.E, G.3, K.163, D.141). Askerî fabrikaların kuruluş tarzı ve idare şeklinin gereği olarak ekonomik ve ticari organizasyon yapısı oluşturulamamıştır. Bu itibarla MKEK'ye askerî fabrikalardan ekonomik ve ticari fonksiyonları bulunan bir teşkilat da katılmamıştır (MKEK Arşivi, R.40, R.E, G.3, K.163, D.141).

Askerî fabrikalar döneminde, MSB ihtiyaçları haricinde, özellikle tekel idaresine patlayıcı madde niteliğinde ürünler yapılmış, ayrıca Devlet Demir Yolları'ndan siparişler alınmıştır. Serbest piyasaya ise çok çeşitli alanlarda ürün üretilmiş, fakat bu hizmetler bedel açısından çok düşük değerlerde kalmıştır. 
Türkiye'de Savunma Sanayi Gelişim Tarihi İçinde Makine ve Kimya

Endüstrisi Kurumunun Kuruluş Dönemi Faaliyetlerinin Analizi

Askerî fabrikalardan, kuruma işletme sermayesi olarak nakit intikal etmediği gibi, devletçe de bu nam altında bir yardımda bulunulmamıştır. Askerî fabrikaların alacak ve borçları 5591 sayılı kanunla kuruma devredilmiş ise de borçların ödenmesi hâlinde alacaklar karşılamadığından kurumun bu hesaplaşma neticesinden faydalanması mümkün olmamıştır (MKEK Arşivi, R.40, R.E, G.3, K.163, D.141).

MKEK'ye askerî fabrikalardan intikal eden tesislerdeki personelin teknik kabiliyetleri yeterli seviyededir. $\mathrm{Bu}$ açıdan bakıldığında sivil kuruluşlardaki personele nazaran daha tecrübeli ve üstün kapasiteye sahiptirler. $\mathrm{Bu}$ personel mesleği ve teknik kabiliyet noktasında olgun, tecrübeli ve yüksek değerdedir. Kurumun 1950 yılı itibarı ile personel durumu şöyledir: (MKEK Arşivi, R.40, R.E, G.3, K.163, D.141).

$\begin{array}{llr}\text { Yüksek mühendis ve mühendis } & : & 99 \\ \text { Memur } & : & 818 \\ \text { Usta } & : 287 \\ \text { Birinci sınıf işçi } & : 1.190 \\ \text { İkinci sınıf işçi } & : 3.189 \\ \text { Sanatsız işçi } & : 2.232 \\ \text { Toplam } & \mathbf{\mathbf { 7 . 8 1 5 }}\end{array}$

1966 y1lına gelindiğinde, kurumda gerek memur ve hizmetli ve gerekse işçi kadroları gerçek ihtiyacın çok üzerine çıkmıştır. Bu dönemde kurumda usulüne uygun ve ihtiyaç çerçevesinde yeniden kadrolaşma ihtiyacı ortaya çıkmıştır. İşletmelerin tamamında 12.424 işçi çalışmaktadır. İşçilere yapılan ödemelerin toplamı 130.601.788 TL olup, bunların 90,3 milyonu iş karşıllı̆ı ödemeler, 40,3 milyon TL'si de çeşitli sosyal yardımlardır. Bir işçiye ödenen ücret ve yapılan sosyal masraflar ayda toplam 876 TL'dir (MKEK Kamu İktisadî Teşebbüsleri Karma Komisyon Raporu- 1966: s.2).

\section{Kuruluş Yıllarında Makine ve Kimya Endüstrisi Kurumunun Gelişim Politikaları}

5591 sayılı kanun ile kurulan Makine ve Kimya Endüstrisi Kurumu, mühimmat, silah, roket, makine, çay, zeytinyağı fabrika tesisleri, zirai mücadele 
aletleri, tekstil makineleri, takım tezgâhları, treyler, kontrplak, çelik malzeme, bakır ve pirinç malzeme, çelik çekme boru, patlayıcı maddeler, boya hammaddesi, pil başta olmak üzere hiçbir kuruluşta görülmeyen çok çeşitli üretim konularını birbirleri ile bütünleştiren bir kamu iktisadi teşebbüsüdür.

Kuruluş kanunu ile MKEK'na, MSB'nin her çeşit silah, mühimmat ve patlayıcı maddeler ile askerî ihtiyaçlara yönelik aletler, vasıtalar, makineler, tesisler ve diğer her türlü eşya yapma ve ihtiyaçları karşılama görevi verilmiştir. Zaman içerisinde bu kurum ülkemizin savunma sanayinin en önemli kuruluşu hâline gelmiş ve gelişimini sürekli olarak sürdürmüştür.

MKEK'nin kuruluşunda, millî savunma ihtiyaçları için mevcut tesislerin, ihtiyaca en iyi cevap verebilecek bir hâle getirilmesi ana hedeftir. Kurum, millî savunma ihtiyaçları için devraldığı kapasite ile değil, bilakis modern harp sanayi ürünlerini üretebilecek seviyede tesisler kurmayı gelişim politikasının en önemli parçası olarak belirlemiştir. Bu kapsamda, 20 Eylül 1951 tarihinde Amerikan askerî heyeti Türkiye'de roket imali için girişimlerde bulunmuş, ilk önce bu silah California'da Institute of Technology'de yapılmaya başlanmış, daha sonra Belçika'da bir tesis kurulmuş ve son olarak da Türkiye'de MKEK'de üretime başlanmıştır (BCA, 640.051, MKEK Yönetim Kurulu Karar Defteri, 4 Ekim 1951: s.54).

MKEK'nin kuruluş yıllarında açılacak yeni fabrika ve tesislerde uygulanan ana prensip ekonomik verimlilik olmuştur. Yeni kurulan tesislerin ucuza mâl edilmesi esas şartlardan biridir. Bu sayede tesislere mümkün olduğu kadar az sermaye bağlanmış olduğu gibi sermaye masraflarının düşük olması dolayısı ile ekonomik açıdan verimliliğin sağlanmasına yardım edilmiştir. Ham malzeme alımında, bunların stoklanmasında, mamullerden yapılacak stok miktarında da mümkün olduğu kadar ucuza almak ve ucuza mâl etmek temel politika olmuştur.

Kurum faaliyet alanlarından birisi de kimya sanayidir. Çok geniş bir üretim alanına sahip olmasından dolayı bu sanayinin her kısmı ile kurumun meşgul olması düşünülemez. Bu alanda millî savunma ihtiyaçlarının karşılanması temel politika olmuştur. Örneğin, kurulacak olan azot fabrikası, suni gübrenin olduğu kadar patlayıcı maddelerinde esasını oluşturması itibarı ile kurumun programı içerisine girmektedir (MKEK Arşivi, R.40, R.E, G.3, K.163, D.141).

Askerî fabrikaların ilk kuruluşunda ve bunların gelişmesinde askerî amaçlar hedeflendiğinden, bu durum üretim ve satış politikalarına da yansımıştır. Kurumun kuruluş yılları itibarı ile fabrikaların bir kısım askerî ihtiyaçlar dışındaki 
Türkiye'de Savunma Sanayi Gelişim Tarihi İçinde Makine ve Kimya

Endüstrisi Kurumunun Kuruluş Dönemi Faaliyetlerinin Analizi

imalâtı da bünyelerine uygun olmak şartı ile yapabilecek durumda ise de alınacak siparişler ve dolayısıyla imalâtın sıklet merkezini millî savunma ihtiyaçları oluşturmaktadır.

5591 sayılı kanunun 3'üncü maddesi, millî savunma ihtiyaçlarından vasıf, zaman ve miktar bakımlarından kurumca karşılanamayacak kısımlar istisna, diğer bütün siparişlerin kuruma verilmesini uygun görmektedir. 1951 yılı itibarı ile ve Cumhurbaşkanı onayı ile MSB'nin en az yılda 20.000.000 TL sipariş vermesi kanuni zorunluluk olarak belirlenmiştir (BCA, 640.051, MKEK Yönetim Kurulu Karar Defteri, 8 Ocak 1951).

Ancak MSB'nin verdiği siparişlerin, MKEK'ye devrinde Askerî Fabrikalar Umum Müdürlüğü devrine nazaran azaldığı görülmektedir. $\mathrm{Bu}$ yüzden kurum tesislerini bazı hâllerde $\% 25$ hatta sıfıra kadar düşen bir imal hacmi ile çalıştırmak zorunda kalmıștır (MKEK Arşivi, R.40, R.E, G.3, K.163, D.141).

Kurum, millî savunmaya için gerekli çeşitli silah, mühimmat ve patlayıcı maddeler ile aletler, vasıtalar, makineler, tesisler her türlü eşya ve levazım, yedek parçalar, seri hâlinde büyük ve küçük ıslah işleri, mevcut imkânların takviyesine ve en ileri düzeye çıkarılmasına çalışmaktadır.

MKEK 1950 y1lında, 5591 sayılı kanun hükümleri gereğince İktisadi Devlet Teşekkülü hâline geldikten sonra, ilk defa 1951 yılı Şubat ayında Amerikan yardım heyeti vasıtasıyla bir Amerikalı uzman olan Alonzo E. Taylor Türkiye'ye gelerek askerî fabrikalarımızda imalât yönünden tetkik ve tavsiyelerde bulunmuştur. $\mathrm{Bu}$ tetkikler içerisinde özellikle, fabrikaların tam kapasite ile çalışamamalarının sebebinin sermayesizlik olduğu sonucuna varılmıştır (MKEK Arşivi, R.40, R.E, G.3, K.116-4, D.384/390).

1952 Şubatında Mr. Cames E. Mullen, Kırıkkale pirinç haddehanesi için gerekli tesisler hakkında bir rapor hazırlamış ve bu rapor doğrultusunda fabrikanın yeniden yapılandırılması sağlanarak elektrolitik bakır tesisleri işletmeye açılmıştır. Yine 1952 yılında Amerika'dan, sıcak kalıpçılık mütehassısı Mr. Mason Türkiye'ye gelmiş ve Kırıkkale Top Fabrikası ile Ankara Silah Fabrikası'nda iki ay süreyle sıcak kalıpçılık üzerine bilgi vermiştir. Bu süre içerisinde, üç ustabaşı ve dört işçi kendisi ile çalışmış ve tecrübelerinden yararlanmıştır (MKEK Arşivi, R.40, R.E, G.3, K.116-4, D.384/390).

1952 yılında Amerika'dan döküm konusunda uzman olan Mr. Canzauze ile kum uzmanı Mr. Henderson kuruma ait fabrikalarda incelemeler yaparak 
tavsiyelerde bulunmuşlardır. Yine 1952 y1lı içerisinde General Wells, Amiral Colbey ve Mister Windsor'dan oluşan bir Amerikan heyeti MKEK fabrikalarını gezerek incelemelerde bulunmuş ve fabrikaların büyük bir imal kapasitesi olduğunu rapor etmişlerdir. Ancak barut fabrikasının boş durması ve fiyatların pahalılığı heyetin dikkatini çekmiştir. Heyet Kırıkkale'deki fabrikaları da gezmiş ve gerek maddi ve gerekse eleman yardımı konusunda güvence vermiştir. Bunun üzerine 5 milyonu malzeme, 2 milyonu tesis olmak üzere toplam 7 milyon TL'lik yardım, heyet tarafından plana alınmıştır (BCA, 640.051, MKEK Yönetim Kurulu Karar Defteri, 48'inci oturum, 6 Mart 1952).

MKEK tesisleri 1950 yılından sonra birincisi Off-Shore, ikincisi Alman siparişlerinin karşılanması için 1954 ve 1958 yıllarında olmak üzere iki defa modernize edilmiştir (Gök, 1976:s.62). Yapılan modernizasyon çalışmalarında askerî fabrikalar için gerekli tezgâh ve makinelerin Avrupa'dan alınması düşünülmüş, ancak bu tezgâhların yeterli derecede verimli olmadığı anlaşıldığından Amerikan tezgâhları alınmış ve bu tezgâhlarda 3 ila 5 makineye bir işçi düştügünden, daha ekonomik ve kullanışlı olduğu tespit edilmiştir (BCA, 640.051, MKEK Yönetim Kurulu Karar Defteri, 55'inci oturum, Karar No:249, 20 Mart1953).

Bunun dışında, fabrika modernizasyonlarında özellikle Alman Meissner firması önemli bir yer tutmaktadır. Yurt dışı siparişlerinin alınması ve zamanında yetiştirilebilmesi için mühimmat, pirinç ve barut fabrikalarında yüksek verimli tezgâh ihtiyacı ortaya çıkmış ve fabrikaların tevsi ve ıslah işleri için Alman Meissner firması ile anlaşma yapılmıştır. Ayrıca mühimmat çarkhanesi, pirinç haddehanesi ve barut fabrikasının bazı tezgâhları için Amerikan yardım heyetinden 1.978.000 dolarlık tedarik müsaadesi alınmıştır (BCA, 640.051, MKEK Yönetim Kurulu Karar Defteri, 48'inci oturum, Karar No:198, 5 Şubat 1953).

Gelişim programının gerçekleşmesinden sonra MKEK'nin 110.413.000 TL'lik iş hacmine, 196.089.000 TL'lik yeni bir iş hacmi ilave edilmiştir. Bu suretle kurumun senelik 3.000.000 TL'lik kârına, 1955 yılını takiben, 1961 yılından sonra 22.805.000 TL'lik bir kâr eklenmiştir. Bu programın başarıyla sonuçlanması ülke ekonomisine önemli bir katkı sağlamıştır (MKEK Ana İnkişaf Programı Raporu, 1954-1959: s.116).

1954 yılında, Amerika'dan gelen E. Shehorn, Off-Shore siparişleri ile ilgili olan dumansız barutların imalinde rastlanan zorlukları ortadan kaldırmak üzere çalışmalarda bulunmuştur. Mühimmat imalâtında karşılaşılan güçlükleri yenme 
Türkiye'de Savunma Sanayi Gelişim Tarihi İçinde Makine ve Kimya

hususunda yardımcı olmak üzere Amerika'dan mühimmat uzmanı Charles George Graxiose Türkiye'ye gelmiş ve fabrikalarda teknik incelemeler yaparak modernize hususlarında tavsiyelerde bulunmuştur.

4 Aralık 1959 tarihinde Türkiye'ye gelen Alman uzman Karl Gulden Almanya'ya satılan 76 ve 90 mm'lik pirinç kovanların imalinde güçlüklere sebep olabilecek faktörleri göstermiş ve konu ile ilgili açıklamalar yapmıştır. Belçika'da bulunan Metallurgia S.A. firmasının müdürü Albert Rassinfrose 21 Kasım 1961 tarihinde askerî fabrikalarda incelemelerde bulunarak rasyonel bir imalât için gerekli bilgi aktarımını sağlamıştır. 17 Nisan 1962 tarihinde Türkiye'ye gelen Albay George A. Miller, hafif silah mühimmatı ile ilgili teçhizat ve tezgâh ihtiyaçlarını ilgilendiren raporu ile Gazi Fişek Fabrikası tesislerinde faydalı olmuştur (MKEK Arşivi, R.40, R.E, G.3, K.116-4, D.384/390).

MKEK kuruluşundan itibaren bir taraftan sivil ihtiyaçlara yönelik üretimleri planlarken diğer taraftan da MSB'nin ihtiyaçları ve dış siparişleri karşılamaya yönelik çalışmalar yürütmüştür. MKEK, 1950 yılında MSB'ye 27.001.263.68 TL tutarında satış yapmış (MKEK Yönetim Kurulu Raporu (1951), s.71). 1951 yılında MSB'ye yapılan toplam satı̧ tutarı ise 11.938.946.40 TL olmuştur (MKEK Yönetim Kurulu Raporu, 1951: s.71).

MSB, MKEK faaliyetleri ile ilgili olarak birtakım şikâyet ve isteklerini İşletmeler Bakanlığı ve Başbakanlık vasıtası ile kuruma iletmiştir. Özellikle siparişlerin vaktinde teslim edilmemesi bu şikâyetlerin başında yer almaktadır. 1951 yılında, 1947 ve 1948 yıllarına ait siparişlerin teslim edilmediği bildirilmiştir. $\mathrm{Bu}$ durumun temel nedeni olarak da kurumun dış ülkelerden aldığı siparişler ve mevcut kapasitenin bunu karşılayamaması olarak değerlendirilmiştir (BCA, 640.051, MKEK Yönetim Kurulu Karar Defteri, 48'inci Oturum, 6 Mart 1952). Ancak bu şikâyetlerin doğmasının temel nedeni kurumun yaşadığı ekonomik sıkıntı ve sermayesizliğidir. 5591 sayılı kanun çıkartılırken, askerî fabrikaların ordunun bütün ihtiyaçlarına cevap vermediğinden, harp sanayimizin her bakımdan gelişmesi, daha üstün bir seviyeye gelebilmesi ve modern ordu isteklerini karşılayacak kabiliyete ulaştırılması bir zorunluluk olarak görülmekteydi. Bunu sağlamak için de kanun, kuruma görev ve yetkiler vermiş, bu işlerin yerine getirilmesi için para kaynakları ayrılmasından bahsetmiştir. Ancak, sermayesizlikten 1950 ve 1951 yıllarında 5591 sayılı kanunun belirttiği istekleri karşılayacak ve alınan siparişleri yapacak tesisler kurulamamış ve 1952 yılında da 
bu aksaklıklar devam etmiştir (BCA, 640.051, MKEK Yönetim Kurulu Karar Defteri, 48'inci Oturum, 6 Mart 1952).

MKEK, Millî Müdafaa Vekâleti, iç piyasa ve dış piyasaya yönelik 19541955 yılları satışları karşılaştırmalı olarak aşağıda verilmektedir (MKEK İcra Meclisi Raporu-1955: s.37).

Tablo 1

\begin{tabular}{|l|c|c|}
\hline \multicolumn{1}{|c|}{ SATIŞ YERİ } & $\mathbf{1 9 5 4}$ (TL) & $\mathbf{1 9 5 5}$ (TL) \\
\hline Millî Müdafaa Vekâleti & 28.743 .090 & 14.196 .703 \\
\hline İç Piyasa & 22.722 .978 & 27.517 .301 \\
\hline Diş Piyasa & 8.382 .825 & 16.701 .854 \\
\hline TOPLAM & 59.848 .894 & 58.415 .859 \\
\hline
\end{tabular}

Kaynak: MKEK İcra Meclisi Raporu (1955), s.37.

Bu tablodan da anlaşıldığı gibi, Millî Savunma Bakanlığı satışları \% 50,6 azalırken, iç piyasa satışlarında \%21,1 oranında artış olmuştur. Özellikle Millî Savunma Bakanlığı siparişlerindeki azalmanın temel sebebi olarak, program ve keşif isabetsizlikleri, siparişlerin zamanında yapılmaması, malzeme ve işçi ücretlerinde yaşanan artma ve bazı fabrikalarda iş hacminin azalması olarak görülmüştür.

1954 yılında, MKEK tarafindan imali zorunlu olan mamulleri işleyecek fabrikaların ve tesislerin rasyonel, verimli, tamamen iktisadî işletme esaslarına göre çalışabilmesi için fabrika ve tesislerin yapacakları iş dikkate alınarak gruplandırılması zorunlu görülmüştür. Bunun sonucunda beş endüstri grubunun kurulmasına karar verilmiştir. $\mathrm{Bu}$ gruplandırma da yer almayan ve savunma malzemesi grubundan olan Ankara Silah, Ankara Marangoz ve Kayaş Kapsül Fabrikaları üniteleri dağıtılarak diğer fabrikalara bağlanmıştır (MKEK Ana İnkişâf Program1 Raporu,1954-1959: s.17).

Oluşturulmasına karar verilen beş endüstri grubu şu şekilde teşkilatlandırılmıştır:

a. Savunma Malzemesi Grubu:

\section{1- Silah Fabrikalart}

I. Kırıkkale Top Fabrikası

II. Kırıkkale Tüfek Fabrikası 
Türkiye'de Savunma Sanayi Gelişim Tarihi İçinde Makine ve Kimya

Endüstrisi Kurumunun Kuruluş Dönemi Faaliyetlerinin Analizi

2- Mühimmat Fabrikaları

I. Kırıkkale Topçu Mühimmat Fabrikası

II. Ankara Fişek Fabrikası

III. Silahtarağa Av Fişeği Fabrikası

IV. Kırıkkale Yeni Fişek Fabrikası

3- Malzeme Fabrikaları

I. Kırıkale Çelik Fabrikası

II. Kırıkkale Pirinç ve Metal Fabrikası

4- Barut ve Patlayıcı Maddeler Fabrikası

I. Kirıkale Barut Fabrikası

II. Elmadă̆ Barut Fabrikası

III. Mamak Gaz-Maske Fabrikası

b. Madeni Malzeme Grubu:

1- Karabük Demir Çelik Fabrikaları

2- Istanbul Eloktrolitik Bakır Fabrikast

c. Motorlu Makineler Grubu:

1- Ankara Döküm Fabrikası

2- Ankara Motor Fabrikası

3- Ankara Traktör Fabrikası

4- Ankara Makine Aksamı Fabrikası

5- Istanbul Ince Mekanik Aletler Fabrikası

6- Ankara Uçak Fabrikası

7- Ankara Ziraat Makine ve Aletleri Fabrikası

8- Ankara Takım Fabrikası

d. Demir Inşaatı ve Sanayi Grubu:

1- Istanbul Döküm Fabrikası

2- Istanbul Demir İnşaat Fabrikası

3- Istanbul Bidon Fabrikasl

4- IIstanbul Umumi Makine Fabrikası

5- Istanbul Mensucat Makineleri Fabrikası

e. Kimya Grubu:

1- Kütahya Kimyevi Gübre Fabrikası (Azot Sanayi)

2- Izmir Soda Fabrikast

3- IIskenderun Süper Fosfat Fabrikası 
Savunma malzeme grubunda yer alan silah fabrikaları TSK'nın hafif silah ihtiyaçlarını karşılamak maksadıyla 1935 yılında kurulan fabrikalar olup, 1939 yılında, "2 Nolu Tüfek İsletmesi" adı altında ve çok kısa bir süre sonra da müstakil bir müdürlüğe dönüşerek faaliyetlerine başlamıştır. Bu fabrikalar önceleri "Mavzer Tüfeği” üretimi yapan ve İkinci Dünya Savaşı yıllarında komple kubuz (Bir silahın, kuyruk, kilit ve doldurma düzenlerini bir araya getiren ana aksam) üretimine yönelen, savaşın sona ermesiyle birlikte bu üretime son veren fabrikalardır. Fabrika da, 1949 yılında av çiftelerinin imalâtına başlanmıştır. 1950 yılında MSB'ye bağlı Askerî Fabrikalar Umum Müdürlügünün MKEK adıyla bir "İktisadİ Devlet Teşekkülüne" dönüşmesiyle birlikte, işletme bu kuruma bağlı bir müdürlük olarak faaliyetlerine devam etmiştir. İşletmenin ad1, 1968 yılında "Silah ve Tüfek Fabrikası" olarak değiştirilmiştir. Makineli tabanca üretimine 1986 y1lında başlamış ve işletmenin mamulleri arasına bir yenisi daha konmuştur. 1999 yılından itibaren yeni tip tüfek üretimine başlanmıştır. 5 Aralık 1990 tarihine kadar üretimlerini aralıksız sürdüren fabrika, bu tarihten itibaren de Silahsan Hafif Silah Sanayi ve Ticaret Anonim Şirketi'ne dönüşerek faaliyetlerini sürdürmektedir.

Mühimmat Fabrikaları ise; temeli 1925 y1lında Askerî Fabrikalar Umum Müdürlügüne bağlı olarak atılan fabrikalardır. Mühimmat Fabrikasında üretilen $15 \mathrm{~cm}$. çapına kadar olan mühimmatların deneme üretimine 1929 yılında başlanmıştır. 1950 yılında, 8 Mart 1950 tarih ve 5591 sayılı kanunla kurulan MKEK'ye devredilmiştir. MKEK 8 Haziran 1984 tarih ve 233 sayılı Kanun Hükmünde Kararname ile kamu iktisadî teşebbüsü olarak yeniden teşkilatlanmış ve Mühimmat Fabrikası da yine bu kuruluşa fabrika olarak bağlanmıştır. Mühimmat fabrikası MKEK yönetim kurulunun 19 Aralık 1990 tarih ve 515 sayılı kararı ile mühimmat fabrikası, hassas mekanik fabrikası, imla fabrikası, şeklinde üç fabrika olarak ayrı ayrı faaliyetlerini sürdürürken, Yüksek Planlama Kurulunun 25 Şubat 1993 tarih ve 93/T-19 sayılı kararı ile MÜHIMMATSAN (Mühimmat Sanayi ve Ticaret A.Ş.) adı altında birleştirilerek 1 Mayıs 1993 tarihinden itibaren faaliyetine başlamıştır.

MKEK'nin 5591 sayılı kuruluş kanununa göre görevi belirlenen Kırıkkale Barut Fabrikasının başlıca faaliyet alanı TSK'nın ihtiyaçlarını karşılamaktır. Ayrıca TSK'nin top, tüfek ve mühimmatı barutlarının imalinin yanında av barutu ihtiyacının karşılanması ve piyasanın selülozik boya imalinde kullandığı lak nitroselülozu ihtiyacını da karşılamaktadır. 
Türkiye'de Savunma Sanayi Gelişim Tarihi İçinde Makine ve Kimya

Endüstrisi Kurumunun Kuruluş Dönemi Faaliyetlerinin Analizi

Kırıkkale Barut Fabrikasının yapım ve montaj ihalesi 4 Aralık 1936 tarihinde Köln-Rottweil kuruluşuna verilmiş, 14 Mayıs 1937 tarihinde fabrikanın temeli atılmış, 1 Kasım 1938 tarihinde deneme üretimine başlanmış ve 1 Mayıs 1939 tarihinde işletmeye alınmıştır ("Türk Harp Endüstrisinin Doğuşu ve Makine Kimya Endüstri Kurumunun Tarihçesi”, Haziran 1979: s.8).

Köln-Rottveil kuruluşu, 1 Kasım 1938 günü, 68 binadan oluşan, fabrikanın yapım ve montajını bitirmiş ve tesisleri deneme işletmesine almıştır. Fabrikada, 8 saatte $700 \mathrm{~kg}$ tüfek barutu ve $700 \mathrm{~kg}$ top barutu olmak üzere toplam $1400 \mathrm{~kg}$ barut üretilmiştir. 1 Mayıs 1939'da, fabrika Köln-Rottveil kuruluşundan teslim alınmış ve Askerî Fabrikalar Umum Müdürlüğünce işletmeye alınmıştır. 1959-1962 yılları arasında yapılan yatırımlarla kapasitesi, 1800 Ton/y1l tek bazlı top barutu üretebilecek şekilde arttırılmıştır. (Modern Silahlar Projesi, Ağustos 1974: s.2).

MKEK yönetim kurulunun 16 Temmuz 1992 gün ve 201 sayılı kararı ile 233 no'lu kanun hükmündeki kararname hükümleri çerçevesinde Kırıkkale Barut Fabrikası'nın Nitrosan Nitroselülöz Sanayi ve Ticaret Anonim Şirketi'ne dönüştürülmesi kararlaştırılmıştır. Yüksek planlama kurulunun 25 Şubat 1993 gün ve 93/1-19 sayılı kararı ile Kırıkkale Barut Fabrikasının Nitroselülöz Sanayi ve Ticaret A.Ş. olarak bağlı ortaklık şekline getirilmesine karar verilmiştir.

Motor ve uçak fabrikasının MKEK'ye devri bu dönemde yaşanan en önemli konulardan biridir. Türk Hava Kurumu Fabrikaları, uçak motoru ve gövdesi imal etmek üzere kurulmuştur. Türk Hava Kurumuna ait motor ve uçak fabrikalarının faaliyetlerinin durma noktasına gelmesi ve verimsiz çalışması sonucunda, bu iki fabrikanın MKEK'ye devri Türk Hava Kurumunun ve hükûmetin ortak kararı ile gerçekleşmiştir (MKEK Arşivi, R.40, R.E, G.3, K.161, D.133.).

THK'nın 31 kişiden oluşan genel kurulu 5 Nisan 1952 tarihinde toplanmış ve burada fabrikanın geleceği tartışılmıştır. Delegelerin bir kısmı yabancı sermaye ile işbirliğini savunurken bir kısmı bu görüşe karşı çıkmıştır. Eski Umum Müdürü General Fikret Karabudak ise fabrikanın MKEK'ye devrine ilişkin görüş belirtmiş ve talep etmiştir (BCA, 640.051, MKEK Yönetim Kurulu Karar Defteri, 48'inci Oturum, 6 Mart 1952).

THK Başkanlığına bağlı motor ve uçak fabrikası 20 Haziran 1952 tarihinden itibaren MKEK emrine girmiştir. Fabrikalar 7,5 milyon TL'lik bir fiyat üzerinden faizsiz olarak yirmi sene sabit taksitlerle ödenmek suretiyle satın 
alınmıştır. Fabrikanın MKEK devri gerçekleşirken aşağıdaki planlama ve faaliyetler yürütülmüştür; (MKEK Arşivi, R.40, R.E, G.3, K.165, D.106).

"MKEK devraldığı bu fabrikalar için verimli ve iktisadi çalışma programları hazırlamış ve derhâl uygulamaya başlamıştır.

Fabrikaların bütün mevcutlarının sayımı ve tespitine derhâl başlanmıştır.

Oluşturulacak bir komisyon sayımın yapılmasını ve cetvellerin tanzimi yaparak imzalayacak ve kuruma teslim edilmiştir.

Fabrikaların kuruma teslim tarihi itibarı ile kati bağlantısı yapılmış siparişlerin listesi çıkarlarak bu siparişlerin işlemlerinin yürütülmesi sağlanmıştır.

Fabrikalar için yeni çalışma esaslarına göre kadroların tanzimine ve bu kadrolarda yer alacak memur ve hizmetlilerin tespitine kadar mevcut kadrolar korunmuş ve özlük hakları saklı kalmıştır." (BCA, 030.01 / 76480.12 / E9).

THK fabrikalarının 1950 bilançolarında yer alan rakamlara göre, her iki fabrikanın sabit kıymetleri bedeli 15.137.630 TL'dir. Esas itibarı ile böyle bir müessesenin mütevazı bir kârla yıllık faaliyetlerini yapabilmesi için 15 ila 20 milyon TL'lik bir imalat hacminin olması zorunluydu. Ancak bu seviyeye ulaşması için 10 seneden daha fazla bir süre geçmesi gerekmekteydi (MKEK Arşivi, R.40, R.E, G.3, K.165, D.106). Fabrikaların taşınmaz malları için, uçak fabrikasının arsa bedeli 180.737 TL, uçak fabrikasının bina bedeli 4.828 .000 TL ve makine ve tesisatın bedeli olarak da 3.400.000 TL değer belirlenmiş, motor fabrikasının geneli için ise 7.488.000 TL fiyat tespiti yapılmıştır (BCA, 640.051, MKEK Yönetim Kurulu Karar Defteri, 43'üncü Oturum, 31 Ocak 1952).

Fabrikalar 01 Temmuz 1952 tarihinde MKEK'ye teslim edilmiş, bu teslimata motor ve uçak fabrikalarına ait bütün arazi, bina, ambar, tesisat ve demirbaşlar dâhil edilmiştir. Bu arada fabrikalara daha önceki tarihlerde verilen sipariş ve taahhütler MKEK'ye geçmiş, alınan avans varsa bu paralar MKEK'ye ödenmiştir (BCA, 640.051, MKEK Yönetim Kurulu Karar Defteri, 14'üncü Oturum, Karar No: 27, 3 Temmuz 1952).

THK imalat tesislerinin MKEK'ye devrinden sonra, kısa sürede MKEK-4 "Uğur" adlı bir eğitim uçağı yerli geliştirme olarak yapıldı. Ancak, bu uçağa yakından bakıldığında uçak 1930'lu yıllarda İngiliz Miles firmasının yaptığı 1941 yılından beri de THK'nın aynı tesislerde lisansla imal ettiği "Hawk" eğitim uçaklarının çok az değiştirilmiş biçimidir (Ulrich, Dieter, Peter, Herbert, 1978: s. 288). 
Türkiye'de Savunma Sanayi Gelişim Tarihi İçinde Makine ve Kimya

Endüstrisi Kurumunun Kuruluş Dönemi Faaliyetlerinin Analizi

Ayrıca bu fabrikalar istenilen düzeye erişinceye kadar mevcut müesseselerde çeşitli tarım aletleri, yol makineleri, motopomplar ve motorlu araç yedekleri yapılmaya başlanmıştır (MKEK Arşivi, R.40, R.E, G.3, K.161, D.133).

1952 yılında Türk Hava Kurumundan motor fabrikası ile beraber MKEK'ye devredilen uçak fabrikası, uçak imalatı üzerine tatmin edici sipariş alamadığı için farklı işler üzerine siparişler almış, tesisat ve teçhizat imkânlarına uygun sürekli bir imalât faaliyetine geçememiştir. Bunun üzerine uçak imalatı ve tamirat1 yanında bünyesine uygun ziraat makineleri, madeni üretim işleri yapılmaya başlanmıştır. Bu fabrika yılda 150-200 eğitim veya benzeri uçak imal etmek üzere kurulmuştur. Fabrika, MKEK'ye devrinden önce 6 tip uçak ve 9 tip planöre ait etüt, adaptasyon ve lisans suretiyle prototipler üzerinde çalışmıştır (MKEK İdare Meclisi Raporu, 1954: s.35).

1955 yılında fabrikanın planlanan ve gerçekleștirilen üretimi aşağıdaki tablodaki gibidir (MKEK İcra Meclisi Raporu, 1955: s.25).

Tablo 2

\begin{tabular}{|l|c|c|c|}
\hline \multicolumn{1}{|c|}{ Mamuller } & \multirow{2}{*}{$\mathbf{1 9 5 4}$ Yılı } & \multicolumn{2}{c|}{ 1955 Yılı } \\
\cline { 3 - 4 } & 25 & Program Adedi & Fiili Adet \\
\hline Uğur Eğitim Uçağı İmali & 19 & 50 & 1 \\
\hline $\begin{array}{l}\text { Magister Eğitim Uçağı Motor } \\
\text { Revizyonu }\end{array}$ & 15 & 3 & 22 \\
\hline $\begin{array}{l}\text { Magister Eğitim Uçağı Gövde } \\
\text { Revizyonu }\end{array}$ & --- & 10 & 23 \\
\hline THK-14 Planörü İmali & --- & 5 & 10 \\
\hline THK- 9 Planörü İmali & --- & --- & 7 \\
\hline THK- 9 Planörü Revizyonu & & -- \\
\hline
\end{tabular}

Kaynak: MKEK İcra Meclisi Raporu (1955), s.25.

Bu tablodan da anlaşıldığı gibi uçak fabrikası 1954 yılından itibaren, yaptığı programları tam manası ile uygulayamamış ve üretimde aksamalar meydana gelmiştir. 


\section{Sonuç}

Savunma sanayi çalışmaları dünya çapında genel olarak değerlendirildiğinde, özellikle İkinci Dünya Savaşı öncesi dönemde mekanize silahların, soğuk savaş dönemi yıllarında ise daha çok yeni teknolojileri gerektiren turbo jet motorların, füzelerin, elektronik ve ileri malzeme teknolojilerin geliştirildiğini ve nükleer silahlar ve balistik füzelerin ön plana çıktığını görmekteyiz. Dünyanın iki blok hâlinde bölünmesi ile başlayan soğuk savaş döneminde savunma sanayi ve savunma teknolojisindeki yarış hızlanmış ve devletler ekonomilerinin önemli bir payını bu alana ayırmışlardır. 1990'lı yılların başından itibaren, bloklar arasında başlayan yumuşama süreci ve Rusya'nın dağılması silahlanma yarışını yavaşlatmış ve ülkeler savunma harcamalarında kısıtlamalara gitmişlerdir. Ancak bu gelişmeler genel olarak yoğun tehdit altındaki ülkeler için geçerli olmamıştır. Değişen dünya koşulları gereği, Avrupa Topluluğu ve Kuzey Amerika ülkelerinde savunma bütçelerine daha az kaynak ayrilırken, Türkiye'ye yönelen tehdit algılamalarında ve bölgesel risklerdeki artış nedeniyle savunma sanayi alanındaki yurt içi faaliyetler daha da önem kazanmıştır.

Uluslararası alanda bir devletin gücü, sahip olduğu askerî güçle değerlendirilmekte ve ölçülmektedir. Askerî alanda yetersiz kalan devletler diplomatik alanda da yeterli etkinlik gösterememektedirler. Genel olarak devletler savunma sanayilerini millî politikalarını uygulayabilmek için bir araç olarak kullanırlar ve güçlü olanlar bu alana da hâkimdirler. Dünya üzerinde çok önemli jeopolitik ve jeostratejik konumda yer alan Türkiye'nin, potansiyel tehdit algılamalarına karşı caydırıcı bir güç oluşturabilmek için çok iyi eğitilmiş ve en ileri teknolojiye sahip silahlarla donatılmış güçlü bir orduya sahip olması gerekmektedir. Türkiye, Orta Doğu, Balkanlar ve Kafkaslar gibi dünyanın siyasi, ekonomik ve askerî olarak en dengesiz bölgelerinin tam ortasında bulunmaktadır. Güçlü savunma ancak yerli ve millî bir savunma sanayi ile mümkündür. Bu da ülkemizin güçlü ve caydırıcı bir savunma sanayine sahip olmasını zorunlu kılmaktadır.

MKEK, 1950 y1lında kuruluşu ile birlikte Askerî Fabrikalar İdaresi yapısından İktisadî Devlet Teşekkülü hâline dönüşerek daha verimli çalışmaya başlamıştır. $\mathrm{Bu}$ süreçte kurumun hızla gelişebilmesi için yerli ve yabancı özel teşebbüs sermayesi ile daha kolay işbirliği yapabilmesi hususlanı dikkate alınarak ana gelişim programıyla MKEK'nin bir anonim şirket hâline dönüştürülmesi 
Türkiye'de Savunma Sanayi Gelişim Tarihi İçinde Makine ve Kimya

Endüstrisi Kurumunun Kuruluş Dönemi Faaliyetlerinin Analizi

prensip olarak kabul edilmiştir (MKEK Ana İnkişaf Programı Raporu, 1954-1959: s.114).

MKEK, savunma sanayi konusunda artan ihtiyaçları karşılamak ve kurum olarak çağın koşullarına uyumlu bir şekilde gelişmek amacıyla sürekli hedef büyütmüş ve büyük projelerin gerçekleştirilmesi için atılımlar yapmıştır. Özellikle tesislerin genel yapıları ve fiziki kapasitelerinden başlanmak üzere birçok alanda çalışmalar yapılmıştır. Fabrika ve tesislerin, gerek fiziki durumları, gerekse hizmet beklentisi bakımından yetersiz olanların ortadan kaldırılması, yenileri ile değiştirilmesi veya rehabilite edilerek hizmete sunulması şeklinde özetlenebilen, idame ve yenileme yatırım çalışmaları aralıksız bir şekilde sürdürülmüştür. Fabrikalarda fiziki ve teknik emniyete ilişkin yatırımlara devam edilmiş, mevcut ürünlerin kalitesinin yükseltilmesi sağlanmıştır (Taşan, 1987: s.11).

Bir ülkenin silahlı kuvvetlerinin en önemli iki unsurundan biri insan, diğeri silah, araç ve gereçlerdir. Türk milleti askerlik mesleğini tarihin ilk dönemlerinden beri kendine düstur edinmiş ve bunu en üst seviyede gerçekleştirmiştir. Ancak, zafere giden yolda insan unsuru tek başına yeterli değildir. Özellikle teknolojideki gelişmeler ve buna bağlı olarak silah, araç ve gereçlerin etkisi her geçen gün artarak devam etmektedir. Silahlı kuvvetlerin modern araç ve gereçlerle donatma ihtiyacı, teknolojik yenilenmeyi hızlandırmış ve bu doğrultuda projeler geliştirilmiştir.

1954 y1lından itibaren MKEK'ye bağlı fabrikaların bir kısmı modernizasyon işlemlerine tabi tutulurken bir kısmının da yeniden kurulmasına karar verilmiştir. Modernize edilen fabrikalar; Kırıkkale Tüfek Fabrikası, Kırıkkale Topçu Mühimmat Fabrikası, Kırıkkale Pirinç ve Metal Fabrikası, Kırıkkale Barut Fabrikası, Elmadağı Barut ve Patlayıcı Maddeler Fabrikası, Silahtarağa Avfişeği Fabrikasıdır. Yeniden kurulacaklar ise; Kırıkkale Fişek Fabrikası, Ankara Döküm Fabrikası, Ankara Ziraat Makine ve Aletleri Fabrikası, İstanbul Bidon Fabrikas1, Kütahya Kimyevi Gübre Fabrikasıdır.

Dünyadaki yeni gelişmeler ve yapılanmalar, ordumuzun modernizasyon ihtiyacı ve bu ihtiyacın olabildiğince olanakları ile karşılanması gerekliliği büyük bir savunma sanayi kuruluşu olan MKEK'ye yeni görevler vermiştir. Kurum mevcut yatırım, işgücü, sermaye, teknoloji kaynaklarını en verimli şekilde kullanımını ilke edinerek, belirlenen hedefler, kalite, mühendislik ve Ar-Ge faaliyetlerinde yoğunlaşmış, günün teknolojisine uygun olarak modernize edilmeye 
çalışılmıştır. Teknoloji ve işgücü altyapısı olarak değişik koşullara uyabilen, mühimmat ve silah sistemlerindeki değişimleri ve gelişmeleri izleyebilen dinamik bir MKEK meydana getirerek, Türk Silahlı Kuvvetlerinin, sektörlerin ve uluslararası piyasa taleplerinin en etkin bir şekilde karşılanabilmesi kurumun ana hedefleri olmuştur (Türk Savunma Sanayi Kuruluşları, 1998: s.157).

\section{Extended Summary}

Defence industry is a community of private and public organizations and enterprises that are designed, developed and produced all kinds of weapons systems necessary for the armed forces of a country and are constantly intertwined with the other industries.

Geopolitical location and geography of Turkey also requires special measures today as the history of each period. Having the control of Straits in Turkey, the natural bridge location between Asia and Europe and having a great army among its allies is a necessary sign of Turkey's potential military power and therefore keeping defence industry at the highest local and natural level.

The Ottoman Empire gave importance to military industrial activities and became a world power in every period. However, the Ottoman Empire, which lagged behind the developments in the world since the 19th century, could not sustain this activity in the last period. In the last years of the State, "General Imalât-l Harbiye-i Directorate" was established in order to recover the military industry field and the studies have been given importance in this field. "General Military Factories Directorate" which was established after the proclamation of Republic took over the activity and responsibility of the war industry between the 1923 and 1950 years.

After the victory of the National Struggle, the researches was started in order to renew the weapon repair shops which were laid in Ankara and to establish the other factories in the Anatolia and Kırıkkale was determined as the most suitable place for this work.

Machinery and Chemical Industry Institution which was established with the law no. 5591 dated March 15, 1950 restructured with the factories and facilities transferred from the General Military Factories Directorate and it has become the main institution of the defence industry. 
Türkiye'de Savunma Sanayi Gelişim Tarihi İçinde Makine ve Kimya

In the introduction section of the article, during the Ottoman Empire, General İmalât-1 Harbiye-i Directorate which is the war industry organization and General Military Factories Directorate organizations is explained. In the first part; the establishment and scope of Machinery and Chemical Industry Institution and general situation of the military factories which are transferred from the General Military Factories Directorate to the Machinery and Chemical Industry Institution are explained. In the second part; the development policies of the Machinery and Chemical Industry Institution in the years of establishment and the factories and facilities belonging to the Machinery and Chemical Industry Institution are explained.

The young Republic of Turkey, experienced the challenges of the Liberty War, has attached importance to the establishment of the national defence industry since their first days and has launched major initiatives. Our country building the aircraft and submarines in these years was also made significant efforts in the 30s and 40 and Machinery and Chemical Industry Institution has been the main center of these activities since 1950.

Machinery and Chemical Industry Institution has continuously expanded its target and has made breakthroughs for the realization of big projects in order to meet the increasing needs of our country in terms of defence industry and to improve itself as an institution. It has made lot of studies by especially starting general structures and physical capacities of the facilities.

The strategic importance, which Turkey has, is a current state in every period of the history. This situation requires a very strong military organization in every period. One of the two most important elements of the armed forces is human and the other is weapons, tools and equipment Especially the developments in technology and correspondingly the effect of weapons tools and equipment are increasing day by day. The need to equip the armed forces with domestic and national modern tools and equipment has accelerated technological renewal and projects have been developed accordingly.

New developments and structures in the world, he need for modernization of our army and the necessity of meeting this need with our own sources as much as possible have given new duties to Machinery and Chemical Industry Institution, which is the first and largest defence industry organization. The instution has concentrated on the targets, quality, engineering and R \& D activities determined by 
using the existing investments, labor force, capital and technology resources in the most efficient manner.

\section{Kaynakça}

\section{Arşiv Belgeleri}

\section{Makine ve Kimya Endüstrisi Kurumu Arşivi}

MKEK Arşivi, R.40, R.E, G.3, K.161, D.133-137.

MKEK Arşivi, R.40, R.E, G.3, K.163, D.139.

MKEK Arşivi, R.40-R.E-G.3, K.163, D.141

MKEK Arşivi, R.40, R.E, G.3, K.163, D.139.

MKEK Arşivi, R.40, R.E, G.3, K.163, D.141.

MKEK Kamu İktisadî Teşebbüsleri Karma Komisyon Raporu (1966), s.2.

MKEK Arşivi, R.40, R.E, G.3, K.116-4, D.384/390.

MKEK Yönetim Kurulu ve Umumî Murakabe Heyeti Raporu (1950), s.61.

MKEK Arşivi, R.40, R.E, G.3, K.163, D.141.

MKEK Arşivi, R.40, R.E, G.3, K.163, D.141.

MKEK Arşivi, R.40, R.E, G.3, K.116-4, D.384/390.

MKEK Yönetim Kurulu Raporu (1951), s.71.

MKEK İcra Meclisi Raporu (1955), s.37.

MKEK Ana İnkişâf Programı Raporu (1954-1959), s.17.

MKEK Arşivi, R.40, R.E, G.3, K.161, D.133.

MKEK Arşivi, R.40, R.E, G.3, K.165, D.106.

MKEK Arşivi, R.40, R.E, G.3, K.165, D.106.

MKEK Arşivi, R.40, R.E, G.3, K.161, D.133.

MKEK İdare Meclisi Raporu (1954), s.35.

MKEK İcra Meclisi Raporu (1955), s.25.

MKEK Ana İnkişâf Programı Raporu (1954-1959), s.114.

MKEK Ana İnkişaf Programı Raporu (1954-1959), s.116.

MKEK İdare Meclisi Raporu (1954), s.19.

Türkiye Cumhuriyeti Cumhurbaşkanlığı, Devlet Arşivleri Başkanlığı, Cumhuriyet Arşivi

BCA, 030.01 / 76480.12 / E9. 
Türkiye'de Savunma Sanayi Gelişim Tarihi İçinde Makine ve Kimya

Endüstrisi Kurumunun Kuruluş Dönemi Faaliyetlerinin Analizi

BCA, 640.051, MKEK Yönetim Kurulu Karar Defteri, 39'uncu oturum, 08.01.1951.

BCA, $030.01 / 76480.12$ / E9.

BCA, 640.051, MKEK Yönetim Kurulu Karar Defteri, 43'üncü Oturum, 31 Ocak 1952.

BCA, 640.051, MKEK Yönetim Kurulu Karar Defteri,14'üncü Oturum, Karar No: 27, 3 Temmuz 1952

BCA, 640.051, MKEK Yönetim Kurulu Karar Defteri, 8 Ocak 1951.

BCA, 640.051, MKEK Yönetim Kurulu Karar Defteri, 55'inci oturum, Karar No:249, 20 Mart1953.

BCA, 640.051, MKEK Yönetim Kurulu Karar Defteri, 48'inci oturum, Karar No:198, 5 Şubat 1953.

BCA, 640.051, MKEK Yönetim Kurulu Karar Defteri, 4 Ekim 1951, s.54.

BCA, 640.051, MKEK Yönetim Kurulu Karar Defteri, 48'inci Oturum, 6 Mart 1952.

BCA, 640.051, MKEK Yönetim Kurulu Karar Defteri, 48'inci Oturum, 6 Mart 1952.

BCA, 640.051, MKEK Yönetim Kurulu Karar Defteri, 48'inci oturum, 6.3.1952.

\section{Kitaplar}

AGOSTON Gabor, Osmanlı' da Strateji ve Askerî Güç, İstanbul, 2012.

TETIK Fatih, SOYLUER Serdal, "Silah İthalatı ve Kara Harp Sanayi”, Dünya Savaş Tarihi - Osmanlı Askerî Tarihi, Kara, Deniz ve Hava Kuvvetleri (1772-1918), İstanbul, 2013.

Ulrich Albrecht- Dieter Ernst- Peter Lock- Herbert Wulf, Silahlanma ve Azgelişmişlik, İran, Hindistan, Yunanistan, Türkiye: Keskinleşen Militarizm, Çeviren: Ümit Kıvanç- Mehmet Budak, İstanbul, 1978, s. 288.

\section{Makaleler}

GÖK Orhan, “ Millî Harp Sanayimiz”, MKEKD, Sayı 12, Aralık 1976.

"Mühimmat Üretimi ve MKEK”, Savunma ve Havacılık, Cilt 7, No:4, Temmuz-Ağustos 1993.

Modern Silahlar Projesi, MKEK Yayını, Ağustos 1974. 
TANYER Turan, "Tophane-i Amire'den Makine Kimya Endüstrisi Kurumuna", MKEKD, Say1 99-100, Nisan 1995.

TAŞAN, Mustafa, Savunma Sanayi ve Makine ve Kimya Endüstrisi Kurumu, MKEK Yayın1, Ankara, 1987.

“Türk Harp Endüstrisi'nin Doğuşu ve Makine Kimya Endüstri Kurumunun Tarihçesi”, MKEKD, Sayı 21, Haziran 1979.

Türk Savunma Sanayi Kuruluşları, MSB Yayını, Ankara, 1998.

YEŞIL Fatih, İhtilaller Çağında Osmanlı Ordusu, Osmanlı İmparatorluğu'nda Sosyoekonomik ve Sosyopolitik Değişim Üzerine Bir İnceleme (17931826), İstanbul, 2016.

\section{Tezler}

ÖZLÜ Hüsnü, “İkinci Dünya Savaşı'ndan Günümüze Türkiye'de Savunma Sanayinin Gelişimi (1939-1990)”, Dokuz Eylül Üniversitesi, Atatürk İlkeleri ve İnkılap Tarihi Enstitüsü Doktora Tezi, 2006, İzmir.

\section{Resmi Gazete}

Resmi Gazete, 15.03.1950, Kanun No: 5591, s.18093. 
EK-1

\section{MAKİNE VE KIMMYA ENDÜSTRİSI KURUMU KANUNU}

Kanun No:5591 (Resmi Gazete ile neşir ve ilanı:15 Mart 1950-Sayı:7457)

\section{BİRINCİ BÖLÜM}

Genel Hükümler

\section{Kurulus}

MADDE 1- (Değişik-22.5 1957 tarih,6973 sayılı kanun madde 7-12.3.1964 tarih,440 sayılı kanun madde-36) 3460(440) sayılı kanuna tabi olmak ve tüzel kişiliğe haiz bulunmak üzere (MAKİNE ve KIMMY ENDÜSTRİ KURUMU) kurulmuştur. Bu Kurum Sanayi ve Teknoloji Bakanlığına bağlıdır. Kurumun merkezi Ankara'dır. Kurum, yurt içinde ve dışında şubeler açılabilir ve temsilciler bulundurabilir.

\section{Kurumun yapacağı işler}

MADDE 2- Kurumun yapacağı işler şunlardır:

a. Her çeşit silah, mühimmat ve patlayııı maddelerle askerî ihtiyaca yarayan aletler, vasitalar, makineler, tesisler ve diğer her türlü eşya levazım ve yedek parçalar imal etmek ve seri hâlinde büyük ve küçük tadil ve islah işlerini ve diğer tamirleri yapmak,

b. Tesisleri ve imkânları ile karşılayabileceği sivil ihtiyaçlara ait her türlü imalat ve tamirat yapmak,

c. 4374 sayıl1 kanunun 1'inci maddesinde yazılı tekel maddeleri yapmak,

d. "a,b,c" fıkralarında sayılan işleri görmek üzere lüzumlu her türlü tesisleri kurmak ve mevcutları da tevsi ve islah etmek,

e. (a) ve (b) fikralarında yazılı maddelerin ticaretini yapmak,

Kurum, yukarıdaki fıkralarda sayılmayıp da kendi iştigal sahasına giren sair işleri de yapabilir.

\section{Millî Savunma Siparişleri}

MADDE 3- Millî Savunma Bakanlığı 2'nci madde mevzuuna giren bütün ihtiyaçlarını Makine ve Kimya Endüstrisi Kurumuna sipariş etmeye mecburdur. 
Bu Bakanlık ihtiyaçları için Kuruma verilecek yıllık siparişler, Bakanlık ve Kurum tarafindan birlikte tespit olunur ve müteakip yıl iş programının tanzime esas olmak üzere evvelinden Kuruma bildirir.

$\mathrm{Bu}$ ihtiyaçlardan vasıf, zaman ve miktar bakımlarından Kurumca karşılanmak kısımlar başkaca satın alınabilir.

Kurum; tesislerini, imkânları dahilinde, Millî Savunma Bakanlığından alacağ1 siparişleri karşılayacak bir hâlde bulundurmaya mecburdur.

Millî Savunma Bakanlığınca, kuruma yapılan siparişler için 2490 sayı1lı kanun hükümleri uygulanmaz. Bu siparişler için, 1050 sayılı kanunun, 83'üncü maddesi gereğince ve karşı1lığında teminat aranmadan sipariş bedelinin en az \%50 nispetinde avans verilir.

\section{Malzeme Stokları}

MADDE 4- Millı̂ Savunma Bakanlığı, bedeli ile muhafaza giderleri Bakanlık bütçesinden ödenmek üzere Kuruma harp ihtiyatı stokları yaptırılabilir. Kurum; bu stokları aynen iade edilmek veya bedeli siparişleri mahsup olunmak şartıyla adı geçen Bakanlığın muvaffakiyetiyle kullanabilir.

\section{İKİNCİ BÖLÜM \\ Malî Hükümler}

\section{Sermaye}

MADDE 5- (değişik 23.3.1971 tarih 1381 sayılı kanun madde 1) Kurumun sermayesi 1.000.000.000 TL'dir.

MADDE 6- Kurumun sermayesi aşağıdaki kaynaklardan terekküp eder :

a) Bu kanunun 18 'inci maddesi gereğince Kuruma intikal edecek her çeşit k1ymetler,

b) Hazineye ait menkul ve gayrimenkul mallarla 19'uncu madde gereğince Kuruma devredilecek tesislerin 7'nci maddeye göre tespit olunacak değerleri,

c) 9'uncu maddeye göre sermayeye eklenecek karlar,

d) Maliye Bakanlığı bütçesine her yıl konulacak ödenekler.

MADDE 7- 6'nc1 maddesinin (B) fikrası gereğince Kuruma devredilecek menkul ve gayrimenkul malların değerleri, Millî Savunma, Maliye ve Sanayi Teknoloji Bakanlıkları ile Yüksek Denetleme Kurulu ve Kurum temsilcilerinden toplu bir heyet tarafindan takdir ve tespit olunur. 
Türkiye'de Savunma Sanayi Gelişim Tarihi İçinde Makine ve Kimya

Endüstrisi Kurumunun Kuruluş Dönemi Faaliyetlerinin Analizi

\section{Krediler}

MADDE 8- Kurum, Bakanlar Kurulu kararıyla faizli veya faizsiz, ikramiyeli veya ikramiyesiz, kara iştirakli veya iştiraksiz uzun vadeli tahviller çıkarılabileceği gibi 15 yıla kadar vadeli istikrazlar yapabilir. Bunların tutarı Kurumun itibari sermayesinin yarısını geçemez.

Malîye Bakanlığı Kurumun yapacağı 10 y1l ve daha uzun vadeli istikrazlara kefalet yapılabilir.

\section{Kâr Taksimi ve İhtiyatlar}

MADDE 9- Elde edilecek kârlardan 3460 sayılı kanun 42'nci maddesine göre ayrımlar yapıldıktan sonra bakiye itibari sermayenin dörtte birine ulaşıncaya kadar fevkalâde ihtiyat olarak ayrilır.

Bu miktarlar dolduktan sonra kâr sermayeye ilave olunur.

Fevkalâde ihtiyatlara Maliye Bakanlığı bütçesine konacak ödeneklerle yapılabilir. Kurumun zararları yukarıda yazılı ihtiyaçlardan oluşur.

\section{Vergi ve Resim Muafiyetleri}

MADDE 10- a. Kurumun Millî Savunma Bakanlığına yapacağı teslimlerde elde edeceği kârlar, kazanç ve buhran vergileriyle zamlarından, gelir ve kurumlar vergisinden ve bu vergiler yerine geçecek olan vergilerden;

b. (Değişik, 20.711953 tarih 6179 sayılı kanun madde 1 ) Kurumunun Millî Savunma Bakanlığına veya memleketimizin de dâhil bulunduğu milletler arası savunma teşkilatına teslim edeceği her türlü malzeme, teçhizat, vasıtalarla yedek parçalarının imalinde ilk madde veya yardımcı madde veya işletme malzemesi olarak kullanılmak üzere kurum tarafindan yabancı memleketlerden getirilecek maddeler (miktarı ve memleket içinde ihtiyaca yeter derecede tedarikinin mümkün bulunmadığ Maliye, Ticaret, Sanayi ve Teknoloji Bakanlıklarının müşterek teklifi üzerine Bakanlar Kurulunca tespit ve kabul edilmek kaydiyla) ithal alınan, Hazineye, Özel İdare ve Belediyelere ait her türlü vergi, resim, harç ve zamlarından ve gümrük ardiye ücretleriyle rıhtım resminden,

c. (b) fikrasında yazılı maddelerden yurt içinde kısmen imal ve istihsal edilip satın alınacaklar Kuruma teslimlerde muamele vergisinden muaftır.

MADDE 11- (15.2.1958 tarih 7076 sayılı kanunla kaldırılmıştır.) 


\section{ÜÇÜNCÜ BÖLÜM İdare ve Murakabe Organları}

MADDE 12- (Bu maddedeki özel hüküm 12.5.1964 tarih 468 sayılı kanunun 9'uncu maddesiyle kaldırılmış ve Kurumun murakabesi aynı kanunla kurulan Türkiye Büyük Millet Meclisi Kamu İktisadi Teşebbüsleri Karma Komisyonuna bırakılmıştır.)

MADDE 13- Kurum ve Müesseselerin işlem ve hesapları üzerinde Türkiye Büyük Millet Meclisi Kamu İktisadi Teşebbüsleri Karma Komisyonu ve Başbakanlık Yüksek Denetleme Kurulunun yapacağı inceleme ve denetlemeler Kurum işlerinin hususiyetine uygun bir şekilde gizli olarak yapılır.

3460 sayılı kanuna göre Başbakanlık Yüksek Denetleme Kuruluna ve diğer mercilere gönderilmesi gereken her türlü kâğıt ve vesikalar, Kurum Genel Müdürlüğünde, Müessese Müdürlüklerinde ve İşletmelerde incelenir. Bunlardan adı geçen kanuna göre Başbakanlık Yüksek Denetleme Kuruluna verilmesi zaruri olanların bu Kurula ve Başbakanlık Yüksek Denetleme Kurulu tarafından hazırlanacak raporların Sanayi ve Teknoloji Bakanlığına ve Kurum Genel Müdürlügüne verilme şekli, Sanayi ve Teknoloji Bakanlığına, Başbakanlık Yüksek Denetleme Kurulu Başkanlığı ve Kurum Genel Müdürlüğü arasında kararlaştırırlar.

$\mathrm{Bu}$ raporların teksir ettirilmesi veya bastırılması Kurum Genel Müdürlügü tarafindan yapılabilir.

Kurum ve müesseselerine ait bilanço, kar ve zarar hesapları, Başbakanlık Yüksek Denetleme raporları ve Türkiye Büyük Millet Meclisi Kamu İktisadi Teşebbüsleri Karma Komisyonu zabıt ve kararları tevzi, neşir ve ilan edilemez.

MADDE 14- (440 sayılı kanun 12.3.1964 tarih değişik)

Kurum biri genel müdür olmak üzere. kişilik bir yönetim kuruşunca idare olunur.

Yönetim Kurulu .......... bir üye sanayi ve Teknoloji Bakanlığının, ..bir üye de Maliye Bakanlığının teklifi üzerine bakanlar kurulu kararıyla tayin olunur.

üyelerin (Genel müdür hariç) hizmet süreleri için 3 yıldır. Süresi bitenlerin yeniden tayinleri caizdir.

Sanayi ve Teknoloji Bakanlığının teklif edilecek üyeden birinin askerî fabrikalarda ve Kurumda veya resmi ve hususi endüstri teşekkül ve 
Türkiye'de Savunma Sanayi Gelişim Tarihi İçinde Makine ve Kimya

Endüstrisi Kurumunun Kuruluş Dönemi Faaliyetlerinin Analizi

müesseselerinde veya Millî Savunma Bakanlığının Makine ve Kimya Sanayi ile ilgili teknik teşkilatında en az beş yıl başarılı hizmet görmüş olmaları şarttır.

MADDE 15- Kurumun bir genel müdür ve lüzumu kadar yardımcısı bulunur. Genel müdür ve yardımcılarının yüksek tahsil görmüş olmaları ve teknik işlerle meşgul olacak yardımcıları da yüksek mühendis olmaları şarttır.

Genel müdür ve genel müdür yardımcıları Sanayi ve Teknoloji Bakanlığının inhası üzerine Bakanlar Kurulunca atanır. (440 sayılı kanunun 10'uncu maddesiyle bu şekli almıştır.)

Genel müdür, Kurumun en büyük icra amiri olup Kurumun bütün iş ve işletmelerinin kanunlara ve tüzüklere, Yönetim Kurulu kararlarına ve Kurumun iştigal konularının icaplarına göre sevk ve idare eder. Genel müdür, tesislerin iç ve dış emniyetinin koruyucu her türlü tedbirleri almak ve uygulamakta yetkilidir.

Genel müdür yardımcıları, genel müdürden alacakları direktif ve yetkiyle onun adina hareket ederler.

\section{Personel İşleri}

\section{DÖRDÜNCÜ BÖLÜM \\ Çeşitli hükümler}

MADDE 16- Millî Savunma Bakanlığı Kurumunun muvaffakiyetiyle personel yetiştirmek için masrafı bakanlık bütçesinden ödenmek üzere Kurum, müessese ve işletmelerinden eğitim ve staj maksadıyla faydalanabilir ve Sanayi ve Teknoloji Bakanlığının isteği üzerine müessese ve işletmelerin sanatkâr erlerle de takviye edebilir.

Sanatkâr erlere ehliyetlerine göre kurumca gündelik verilir bu taktirde bunlara Millî Savunma Bakanlığı Bütçesinden aylık, yiyecek ve giyecek gelirleri verilmez.

MADDE 17- Kurum, teknik ve personel ihtiyacının karş1lamak üzere yurt içinde ve dışında öğrenci okutabileceği gibi kendine lüzumlu mütehassıs elemanları da yetiştirir.

\section{Kuruma İntikal Edecek Tesisler}

MADDE 18- Aşağıda yazılı fabrika ve tesislerle Askerî Fabrikalar Genel Müdürlügü ve Grup Müdürlüklerinin bütün menkul ve gayrimenkul mevcutları alacak ve borçları 2013-2236 sayılı kanunlar gereğince işletmekte olan döner 
sermayelerle bundan mütevellit alacak ve borçlar ve çeşitli kanun ve tüzüklerle askerî fabrikaların tanınmış olan bütün hakları ve yetkileri bu kuruma intikal eder.

1- Kırıkkale'deki fabrika ve tesisler, diğer büyük binalar,

2- Elmadağ Barut ve Patlayıcı Maddeler Fabrikaları,

3- Ankara Fişek Fabrikası,

4- Ankara Silâh Fabrikası,

5- Ankara Marangoz Fabrikas1,

6- Mamak Gaz ve Maske Fabrikası

7- Kayaş Kapsül Fabrikası ve Mermi İmalathanesi,

8- Bakırköy Barut Fabrikası,

9- Silâhtarağa Av Fişeği Fabrikası

MADDE 19- 18'inci maddede yazılmış olanlar dışında kalıpta Millî Savunma Bakanlığınca işletilen fabrika ve sabit tamirhaneler, Kurumun isteği ve Millî Savunma ve Sanayi ve Teknoloji Bakanlıklarının teklifi üzerine ilerde Bakanlar Kurulu kararıyla 18'inci madde hükümlerine göre devredilebilir.

Şu kadar ki sözü edilen tesisler içinde doğrudan doğruya istihsale yarayan makineler, alet, edevat, malzeme ve hurdalar Kurumun isteği üzerine Millî Savunma ve Sanayi ve Teknoloji Bakanlıklarının kararıyla Kuruma intikal eder ve bunların kıymetleri ödenmiş sermayeye ilave olunur.

MADDE 20-18'inci ve 19'uncu madde hükümlerine göre yapılacak devir, intikal, ferağ ve tescil işlemlerinden dolayı hiçbir vergi, resim ve harç alınmaz.

MADDE 21- Kurumun çalışma konularına giren işler için lüzumlu olan arazi, arsa ve binalardan özel kişilere ait olanlar, Genel müdürün teklifi ve Yönetim Kurulunun kararı ve Sanayi ve Teknoloji Bakanının tasvibi ile İstimlak Kanunu hükümlerince kamulaştırabilir.

(21'inci maddenin 2'nci fikrası 6830 say1l Kanunun 122'nci maddesi ile değiştirilmiş sonradan 30'uncu ve 35 'inci maddeleriyle kaldırılmıştır.)

MADDE 22- Kurumun ve kuracağı müesseselerin malları, devlet mallarının hak ve rüçhanlarını haizdir.

MADDE 23- (21.7.1950 tarihli 5675 sayılı kanun ile kaldırılmıştır.)

\section{Emniyet ve Muhafaza}

MADDE 24- a. Kurum ve müesseselerine ait fabrikalar, atölyeler, depolar ve diğer binalar 1110 sayılı Askerî Memnu Mintıkalar Kanununun uygulanması bakımından askerî mebaniden sayılır. 
Türkiye'de Savunma Sanayi Gelişim Tarihi İçinde Makine ve Kimya

Endüstrisi Kurumunun Kuruluş Dönemi Faaliyetlerinin Analizi

Bunlardan askerî müfrezeler tarafindan muhafazasına lüzum görülecekler mahal ve zaman itibariyle Millî Savunma ve Sanayi ve Teknoloji Bakanlıklarınca birlikte tespit olunur.

b. Kurum ve müesseselerine ait bütün işyerlerinde siyasi maksatla toplantılar, nümayişler yapılamayacağı gibi bu maksatla Kurum mensuplarına sözlü veya yazilı telkinlerde bulunulamaz.

c. (b) fikrası hükmüne muhalif hareket edenlerle Türk Ceza Kanunu'nun 141 ve 142'nci maddelerinde yazılı suçları Kurum ve müesseseleri mensupları arasında işleyenler Askerî Ceza Kanunu'nun 148'inci maddesinde yazılı cezalar uygulanır.

d. Kurum topluluğunda vazife alacak olan bilumum memurlar yabanc1 kadınla evlenemezler. Evlenmiş olanlarla evlenecekler hakkında 1393 sayılı kanun hükümleri uygulanır. (24. maddenin (d) fikrasının 2'nci cümlesi Anayasa Mahkemesinin 22.5.1963 tarih 1963/205-123 sayılı iptal kararıyla hükümsüz kalmıştır).

\section{Tüzük Yapılması}

\section{Kaldırılan kanunlar}

MADDE 25- Bu kanunun uygulama suretini gösterir bir tüzük yapılır.

MADDE 26 - Askerî Fabrikalar Genel Müdürlügüne mütedair. Sermaye verilmesine dair olan 2013 sayılı Kanunla buna Ek 2263 sayılı Kanun kaldırılmıştır.

\section{BEŞINCİ BÖLÜM \\ Geçici hükümler}

\section{Başlangıç Bilançosu}

GEÇİCI MADDE 1- Kurumun bu kanunun yürürlüğe girdiği tarih itibariyle bir başlangıç bilançosu tanzim olunur.

Başlangıç bilançosunun aktifine:

a. 18'inci medde gereğince Kuruma intikal edecek bütün menkul ve gayrimenkullerin defter kıymetleri,

b. Bunlardan bugünkü değerleri defter kımetlerinden aşağı olanlar veya defter kıymetleri olmayanlar, Sanayi ve Teknoloji Bakanlığınca tayin edilecek ve Millî Savunma Bakanlığınca bir temsilcisini de ihtiva edecek uzmanlar heyeti vasıtasıyla ve Sanayi ve Teknoloji Bakanlığınca belirtilecek esas ve şartlar dahilinde takdir edilecek kıymetleri, 
c. Askerî Fabrikalar Genel Müdürlügünün ve 2013, 2236 say1lı Kanunlar gereğince işletilmekte olan döner sermayelerin nakit ve alacakları derç olunur.

Başlangıç bilançosu pasifine:

a. Askerî Fabrikalar Genel Müdürlüğünün ve 2013, 2236 sayılı Kanunlar gereğince işletilmekte olan döner sermayelerin borçları,

b. Bilançonun aktifine ait kıymetler arasında yer alacak olup Millî Savunma Bakanlığına teslimi gereken her nevi imalât safhası tamamlanmış veya tamamlanmamış mamullerin aktifteki bedelleri.

c. Çürük alacaklar için usulü dairesinde ayrılacak karşıllklar derç olunur.

$\mathrm{Bu}$ suretle aktif ve pasif kısımlarına derç olunan kıymetler toplamı arasında fark 6'ncı maddenin (a) fikrasında yazılı sermayeyi teşkil eder.

Kurumun ilk hesap yılı Kanunun yürürlük tarihinden başlar ve müteakip hesap yılının 11'inci maddede yazılı başlangıç tarihine kadarki zamanı da içine alır.

GEÇICI İ MADDE 2- Geçici 1'inci maddenin pasif kısmı (b) fikrasında sözü edilen mamullerden her nevi imalat safhası tamamlanmış olanlarla devir tarihinde yarı hâlde mamul olup Millî Savunma Bakanlığınca ikmalden vazgeçilmiş olan siparişler bedelsiz Millî Savunma Bakanlığına teslim olunur.

İkmal edilecek yarı mamuller ise ikmal edildikten sonra Millî Savunma Bakanlığına teslim olunur ve ikmalleri için Kurumca yapılan masraflar, nispetinde ilave olunacak karlarla birlikte Millî Savunma Bakanlığına tahsil olunur.

GEÇİCİ MADDE 3- a. Kurum ve müesseselerin içişleri hakkında, müktesep hakları ihlal etmeyecek surette özel bir kanunla işçi sigortalarına devir olunacağ 1 kadar 26.01.1939 tarihli ve 3575 sayılı Kanun hükümlerinin uygulanmasına devam olunur.

b. 17.02.1954 tarih ve 6271 sayılı Kanunla kanun gereği kaldırılmıştır.

c. 3575 sayılı Kanuna göre Millî Savunma Bakanlığı bütçesinden sandığa yapılmakta olan $\% 3$ ve 5 nispetindeki ödemeler kendi mensupları için Kurum tarafindan yapilır.

d. Sandık Yönetim Kuruluna Askerî Fabrikalar Genel Müdürlügünce seçilmiş olan 4 üyenin görevleri bu Kanunun yürürlügü tarihinde hitam olunur. Yerlerine Kurum mensupları arasından 4 üye aynı esaslar dâhilinde Kurumca seçilir.

e. 26.01.1939 tarihli ve 3575 sayılı Kanunun 2'nci maddesiyle Askerî Fabrikalar Genel Müdürlüğüne verilmiş olan Yönetim Kurulu Başkanlığ1 görevi Kurum Genel Müdürlüğüne ait olup aynı Kanunun 8'inci ve 44'üncü maddelerinde 
Türkiye'de Savunma Sanayi Gelişim Tarihi İçinde Makine ve Kimya

yazılı yetkilerden Kurum ve Müesseseleri mensuplarının taalluk edenler Kurum Genel Müdürlüğünce kullanılır.

(Askerî Fabrikalar Tekaüt ve Muavenet Sandığg 991 sayılı Kanunla Sosyal Sigortalar Kurumuna devredilmiştir.)

GEÇİCI MADDE 4- a. 18'inci maddede yazılı yerlerde çalışan subay, askerî memur ve sivil aylıklı memurlardan Kurumda görevlendirileceklerle keyfiyet ve kanuni neşrini müteakip yazıyla bildirilir. Bunlar söz edilen tebliğden itibaren 15 gün zarfında Kurumda vazife alıp almayacaklarını yazılı olarak Millî Savunma Bakanlığı ile Askerî Fabrikalar veya Kurum Genel Müdürlügüne bildirirler.

Kendilerine tebligat yapılmayanlarla vazife kabul etmeyenler Millî Savunma Bakanlığ teșkilatında kalırlar.

Kurumda vazife alacak subay ve askerî memurların, 1076 sayılı kanun ile ek tadilleri hükümleri mahfuz kalmak üzere, Kurumda vazifeye tayinleri tarihinden itibaren muvazzaflık sıfatları hitam bulur.

$\mathrm{Bu}$ suretle Kurumda kalacakların tayin tarihine, Millî Savunma Bakanlığı teşkilatında kalacakların ayrılma tarihine kadar Kurumda geçen hizmetleri için ordudaki bütün hakları mahfuzdur.

Kurumun kesin teşkilat kadroları tespit oluncaya kadar uygulanacak ilk kadrolar, "Askerî Fabrikalar" veya "Kurum Genel Müdürlüğü”nce hazırlanır ve İşletmeler Bakanının tasdikine sunulur.

$\mathrm{Bu}$ konudaki tebliğ işleri "Askerî Fabrikalar" ve "Kurum Genel Müdürlüğü’nce yapılır.

b. (a) fikrasındaki işlemler tamamlanıncaya kadar, kanunun yürürlüğü tarihinde "Askerî Fabrikalar"da çalışmakta bulunanları aylık, ücret ve bütün istihkakları, özel kanunlarına göre emsali gibi işleme tabi tutulur. Ödemeler Kurum tarafindan yapılır. Bu işlemler 30 Nisan 1950 tarihini geçmez.

c. Askerî Fabrikalar (Kara, Deniz, Hava) ve Millî Savunma Bakanlığ hesabına tahsil ettirilerek yetiştirilmiş ve hâlen Millî Savunma Bakanlığ 1 teşkilatında çalışmakta olan subay ve askerî yüksek mühendis, mühendis ve kimyagerler müracaat takdirle Millî Savunma Bakanlığının ve Kurum Genel Müdürlügünün muvafakatleriyle Kuruma nakledilirler.

d. 18'inci maddede yazılı yerlerde çalı̧an subay, askerî memur ve sivil aylıklı memurlardan Millî Savunma Bakanlığı teşkilatında çalışmasına lüzum 
görülenler bu kanunun yürürlüğü tarihine kadar Millî Savunma Bakanlığınca "Askerî Fabrikalar"dan alınabilirler. Bunlar istedikleri ve "Askerî Fabrikalar"ca da muvafakat edildikleri takdirde Millî Savunma Bakanlığı teşkilatına geçerler.

GEÇİCI MADDE 5- Geçici 4'üncü maddeye göre Kurumda görev alacaklardan mecburî hizmeti bulunanlar tahsile gitmeden evvel taahhüt ettikleri mecburi hizmetlerinden bakiye hizmetlerini doldurmadıkça; subay ve askerî memurlar 15 senelik istifa sürelerini tamamlamadıkça Kurumdan ayrılamazlar. Bunlardan hem istifa hem mecburî hizmet süresine tabi olanlar istifa süreleri dolduktan sonra mecburî hizmet sürelerini ikmâl etmemişlerse bu bakiye süreyi de tamamlamağa mecburdurlar.

Ayrılanlardan mecburi hizmeti olanlar hakkında taahhütleri gereğince takibat yapılacağı gibi askerlikten geçenlerden ayrılanlar hakkında da askerî şahıslar hakkındaki müeyyideler uygulanır.

GEÇICI I MADDE 6- 18'inci maddede yazılı yerlerde, bu kanunun yürürlüğe girdiği tarihte muvazzaf veya ihtiyat askerlik hizmetlerini yapmakta olan yedek subaylarla harp sanayi erleri terhislerine kadar hizmetlerine Kurumda devam ederler. Bunlar hakkında 16'ncı madde hükümleri uygulanır.

GEÇİCI MADDE 7- Askerî Fabrikalar hesabına "Bölge Sanat Okulları"nda veya "Sanat Enstitüleri"nde tahsilde bulunanların tahsilleriyle ilgili her türlü işlemleri ve mecburi hizmet taahhütleri Kuruma intikal eder. Bunların giderleri Kurumca karşılanır.

GEÇİCI MADDE 8- Bu Kanun yürürlüğe girdiği tarihte Askerî Fabrikalar Genel Müdürlüğü ihtiyacı için memleket içinde veya dışında tahsilde bulunan askerî memur öğrencilerle öğrenime gönderilmeden önce askerî fabrikalar topluluğunda çalışmış olan subay öğrencilerin Kurum Genel Müdürlüğünce kanunun yürürlüğü tarihinden itibaren 15 gün zarfında hazırlanıp gönderilecek yazı üzerinde Kurum emrine geçip geçmeyeceklerini kendilerine tebliğ tarihinden itibaren en çok üç ay içinde Millî Savunma Bakanlığına ve Kurum Genel Müdürlügüne yazılı olarak bildirmeleri şarttır.

GEÇİCI MADDE 9- 18'inci maddede sayılan yerlerde çalışanlardan kurumda hizmet alacak subay ve askerî memurlara bir defaya mahsus olmak üzere 500 TL giyim parası kurum tarafından verilir.

GEÇİCI MADDE 10- Askerî Fabrikalar kadrosunda yer almış olan muhafaza birlikleri; kadroları, teşkilat ve masraflarıyla, Millî Savunma Bakanlığı emrine geçmekle beraber muhafaza hizmetlerine devam ederler. $\mathrm{Bu}$ muhafaza 
Türkiye'de Savunma Sanayi Gelişim Tarihi İçinde Makine ve Kimya

Endüstrisi Kurumunun Kuruluş Dönemi Faaliyetlerinin Analizi

hizmeti Millî Savunma ile Sanayi ve Teknoloji Bakanlıklarının müştereken karar verecekleri tarihte sona erer.

GEÇİCİ MADDE 11- Askerî Fabrikalar Genel Müdürlüğü 1950 yı1lı bütçesinin toplamı olan 23.210.024 TL, bu kanun yürürlüğü tarihindeki bakiye ödenek Millî Savunma Bakanlığı Kara Kuvvetleri 1950 yılı bütçesinde açılacak özel bölüme aktarılmıştır.

Millî Savunma Bakanlığı kadrolarına geçecek subay, askerî ve aylıklı sivil memurların aylık ve diğer istihkaklarına açıkta kalacak subay ve askerî aylıklı sivil memurların açık aylarına yetecek ödenek ve muhafaza birliklerinin bilumum giderleri karşılığı bu bölümden Millî Savunma Bakanlığının Kara Kuvvetleri 1950 yılı bütçesinin ilgili tertiplerine, Millî Savunma Bakanlığının teklifi üzerine teklifi Maliye bütçesinin ilgili tertiplerine, Millî Savunma Bakanlığının teklifi üzerine Maliye Bakanı tarafindan aktarılır. Bu bölümün bakiye ödeneği Millî Savunma Bakanlığınca yapılacak sipariş karşıllı̆̆ olarak bu kanunun 3. maddesi gereğince Kuruma ödenir.

Yapılacak siparişe mahsuben Kuruma Millî Savunma Bakanlığı tarafından 1 Nisan 1950 tarihinde 15 milyon TL avans olarak verilir.

GEÇİCİ MADDE 12- Bu Kanun hükümleri dairesinde Kuruma intikal eden tesisler 3460 sayılı Kanunun 26'nc1 maddesi gereğince müessese hâline getirilinceye kadar yine aynı maddenin 2'nci fikrasına göre Kuruma bağlı teşebbüsler hâlinde idare olunur.

GEÇİCI MADDE 13-19'uncu madde gereğince Kuruma geçecek tesislerde çalışan personelden Kurumda hizmet alacaklar hakkında da bu kanunun geçici 3, 4, 5 ve 9'uncu madde hükümleri uygulanır.

MADDE 27- Bu Kanunun geçici 4'üncü maddesi hükmü yayımı tarihinden itibaren, diğer hükümleri 31 Mart 1950 tarihinde yürürlüğe girer.

MADDE 28- Bu Kanunu Bakanlar Kurulu yürütür. 


\section{SAYILI MAKINNE ve KİMYA ENDÜSTRISI KURUMU KANUNA} EK KANUN

Kanun No. : 6411

Kabul tarihi : 9.6.1954

MADDE 1- Makine ve Kimya Endüstrisi Kurumuna ait Motor Fabrikasının ve bu fabrika ile ilgili tesislerin traktör sanayi ile meşgul olmak üzere Türkiye'de kurulacak anonim şirketlere, Sanayi ve Teknoloji Bakanlığının teklifi ile İcra Vekilleri Heyetinin kararı ile kısmen veya tamamen kiralanması veya satılması veyahut Kurumun iştirak payı olarak devri caizdir.

MADDE 2- Birinci maddede yazılı fabrikanın bununla ilgili tesislerin devir veya satışa esas olacağı kıymeti, Maliye ile Sanayi ve Teknoloji Bakanlıklarının ve Başbakanlık Yüksek Denetleme Kurulunun seçecekleri birer temsilcinin iştirak edeceği bir heyet tarafindan tespit ve takdir olunur.

MADDE 3- İkinci madde gereğince tespit ve takdir olunacak değerle devredilecek veya satılacak fabrika ve tesislerin iktisap bedeli ile bu değerleri arasındaki fark devir veya satışın tahakkuk eylemesi hâlinde Kurumun ödenmiş sermayesine ilave olunur. Bu farktan alınan her türlü vergi, resim ve harçlar da bütçeye irad ve masraf kaydı suretiyle Kurumun ödenmiş sermayesine ilave edilir.

GEÇİĊ MADDE - Kurumun devlet daire, teşekkül ve müesseselerine karş1 olan ve birinci maddedeki fabrika ve tesislerle ilgili bulunan taahhütlerin kısmen veya tamamen veyahut zamanında yerine getirilmemesi bu fabrika ve tesislerin kiralanmasından, satılmasindan veya devrinden veyahut bu maksatlara matuf hazırlık tedbirlerinden tevellüt ederse Kurum zarar ve ziyan ile ilzam edilemez.

MADDE 4- Bu kanun neşri tarihinde meriyete gider.

MADDE 5- Bu kanunu İcra Vekilleri Heyeti yürütür. 